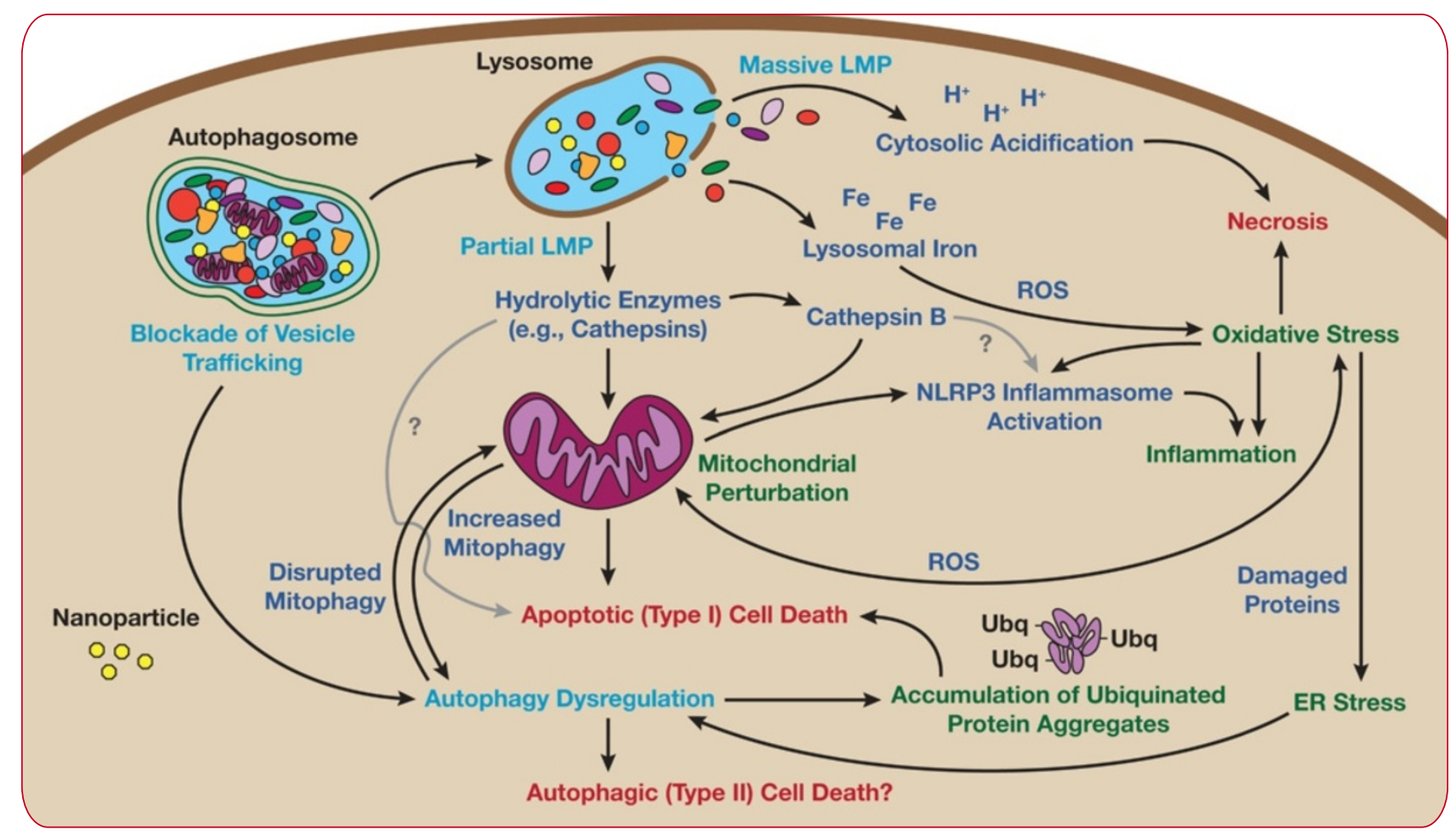

\title{
Autophagy and lysosomal dysfunction as emerging mechanisms of nanomaterial toxicity
}

Stern et al. 


\title{
Autophagy and lysosomal dysfunction as emerging mechanisms of nanomaterial toxicity
}

\author{
Stephan T Stern*, Pavan P Adiseshaiah and Rachael M Crist
}

\begin{abstract}
The study of the potential risks associated with the manufacture, use, and disposal of nanoscale materials, and their mechanisms of toxicity, is important for the continued advancement of nanotechnology. Currently, the most widely accepted paradigms of nanomaterial toxicity are oxidative stress and inflammation, but the underlying mechanisms are poorly defined. This review will highlight the significance of autophagy and lysosomal dysfunction as emerging mechanisms of nanomaterial toxicity. Most endocytic routes of nanomaterial cell uptake converge upon the lysosome, making the lysosomal compartment the most common intracellular site of nanoparticle sequestration and degradation. In addition to the endo-lysosomal pathway, recent evidence suggests that some nanomaterials can also induce autophagy. Among the many physiological functions, the lysosome, by way of the autophagy (macroautophagy) pathway, degrades intracellular pathogens, and damaged organelles and proteins. Thus, autophagy induction by nanoparticles may be an attempt to degrade what is perceived by the cell as foreign or aberrant. While the autophagy and endo-lysosomal pathways have the potential to influence the disposition of nanomaterials, there is also a growing body of literature suggesting that biopersistent nanomaterials can, in turn, negatively impact these pathways. Indeed, there is ample evidence that biopersistent nanomaterials can cause autophagy and lysosomal dysfunctions resulting in toxicological consequences.
\end{abstract}

Keywords: Lysosome, Endocytosis, Autophagy, Nanomaterials

\section{Introduction}

Nanotechnology is an ever evolving field focused on the study of nanoscale materials. Recent applications of nanotechnology include material science, medicine and electronics. Concurrent with research into the application of nanotechnology is the study of potential risks associated with the manufacture, use, and disposal of nanoscale materials, and mechanisms of their toxicity. In order for the continued advancement of nanotechnology and its commercialization, it is important that these associated risks be identified and mediated. Currently, the most widely accepted paradigms of nanomaterial toxicity are oxidative stress and inflammation, but the underlying mechanisms are poorly defined [1]. This review will highlight the significance of autophagy and lysosomal dysfunction as emerging mechanisms of nanomaterial toxicity.

\footnotetext{
* Correspondence: sternstephan@mail.nih.gov

Nanotechnology Characterization Laboratory, Advanced Technology Program, SAIC-Frederick, Inc., NCI-Frederick, Frederick, MD 21702, USA
}

Endocytosis of nanomaterials by both phagocytic and non-phagocytic mechanisms most often culminates with lysosome internalization. The acidic $\mathrm{pH}$ and variety of hydrolytic enzymes (e.g., esterases, proteases, phosphatases, nucleases, and lipases) found in the lysosome represent an extremely hostile environment which can degrade all but the most biopersistent of these nanomaterials. In addition to the endo-lysosomal pathway, recent evidence suggests nanomaterials can also induce autophagy [2]. Among the many physiological functions, the lysosome, by way of the autophagy (macroautophagy) pathway, degrades intracellular pathogens, damaged organelles and long-lived proteins [3]. Thus, autophagy induction by nanomaterials may be an attempt to degrade what is perceived by the cell as foreign or aberrant. While the autophagy and endo-lysosomal pathways have the potential to influence the disposition of nanomaterials, there is also a growing body of literature suggesting that biopersistent nanomaterials can, in turn, negatively impact these pathways [2]. Indeed, lysosomotropic agents, including particles, have been 
known to cause lysosomal dysfunction and associated toxicity for several decades [4].

\section{Endo-lysosomal pathways}

There are several potential pathways that can be involved in nanomaterial cellular uptake. Physicochemical properties of nanoparticles such as size, shape, and surface (e.g., charge and coating), as well as the cell type, all play a significant role in determining the predominant uptake pathway(s). For a more detailed discussion of the pathways utilized by specific nanomaterials, and commonalities with regard to cell types and nanomaterial characteristics, the reader is directed to several excellent reviews on the subject [5-7]. For review of imaging, inhibitor and quantitative methods used in delineating nanomaterial endocytic pathways, and issues associated with interpretation of these experimental methods, the reader is directed to the following literature [8-11].

Phagocytosis is an energy- and receptor-dependent uptake process involving invagination of the plasma membrane and subsequent fusion with lysosomes [12]. A cartoon depicting particle internalization by phagocytic and non-phagocytic pathways is shown in Figure 1. In the phagocytic process of cellular uptake, actin filaments play a critical role, and inhibition of actin polymerization by cytochalasin $\mathrm{D}$ disrupts this internalization process. Phagocytic vesicles containing the ingested material fuse with the lysosomes to form phagolysosomes. The contents of the phagolysosomes are then degraded by enzyme-catalyzed hydrolysis. Phagocytosis takes place in specialized cells such as macrophages, monocytes and neutrophils, and functions in removing foreign particles [13]. The phagocytic pathway can utilize the binding of serum proteins (opsonins) to foreign particles, such as pathogens and nanomaterials, to aid recognition by specific macrophage receptors in a process termed opsonization [13]. Surface modification of nanomaterials with hydrophilic polymers such as polyethylene glycol, polyethylene oxide, and poloxamers can significantly reduce the opsonization of nanoparticles by serum proteins $[14,15]$. Avoiding recognition by the phagocytic cells of the mononuclear phagocytic system (MPS) (mainly liver and spleen) through surface coating can increase nanomedicine circulation, target cell exposure, and efficacy.

Non-phagocytic endocytosis (pinocytosis) can occur in most cells by several recognized mechanisms - clathrinmediated endocytosis, caveolin-mediated endocytosis, clathrin- and caveolin-independent mechanisms, and actin-dependent macropinocytosis [12]. Several endocytic processes may be operative simultaneously in a cell, and the mechanism of uptake of a nanoparticle may vary within and between different cell types [5-7]. Clathrin mediated endocytosis (CME) is commonly involved in the transport of macromolecules, and receptor-dependent CME (e.g., transferrin and epidermal growth factor receptor (EGFR)) is a well understood pathway [12,16]. Endocytosis by this pathway occurs through the invagination of plasma membrane regions having a high density of the cytosolic protein triskelion clathrin. Both receptordependent and independent CME results in eventual lysosomal sequestration, following movement of entrapped materials from early endosome to the late endosome, finally merging with lysosome to form the lysosomeendosome hybrid. Caveolin-mediated endocytosis (CvME), another mechanism of non-phagocytic endocytosis, occurs through a flask-shaped invagination of the plasma membrane [12]. As this pathway does not merge with lysosomes, pathogens have been shown to take advantage of this pathway to escape lysosomal enzymatic degradation $[17,18]$. Likewise, designing nanomedicines to target delivery of agents through CvME, thus avoiding degradation by the lysosomal enzymes, can be beneficial. For example, plasmid DNA delivery in KB cells (a sub-line of the cervical carcinoma HeLa cell line) by PEGylated, folate-targeted nanoparticles utilizes the CvME pathway [19].

Macropinocytosis and other routes of clathrin- and caveolae-independent endocytosis are less well understood pathways. Macropinocytosis involves the internalization of particles greater than $1 \mu \mathrm{m}$ [12]. Macropinocytosis is an actin-dependent process resulting in internalization of particles via cell membrane "ruffling". Endocytosis of particles by this pathway results in the formation of large endocytic vesicles called macropinosomes, which eventually merge with the lysosomal compartment. Cellular uptake of titanium dioxide nanoparticles in human prostate cancer cells has been shown to occur by macropinocytosis, in addition to clathrin- and caveolae-mediated endocytic routes [20].

\section{Autophagy}

The macroautophagy pathway (defined in this review as "autophagy") was first described by Christian De Duve in 1963 [21]. Autophagy (literally "self-eating") involves the sequestration of cargo (e.g., cellular organelles, proteins, pathogens) in double-membrane structures called autophagosomes [3] (see Figure 2). The fusion of autophagosomes with lysosomes, forming autolysosomes, results in the breakdown of encapsulated materials to components which are then available for cell growth and homeostasis. Recently, tremendous progress has been made in characterizing the autophagy protein machinery and signaling cascades, resulting in an explosion of applied research in autophagy [3]. As described in detail below, a growing body of literature suggests that intracellular nanoparticles may undergo autophagic sequestration, 


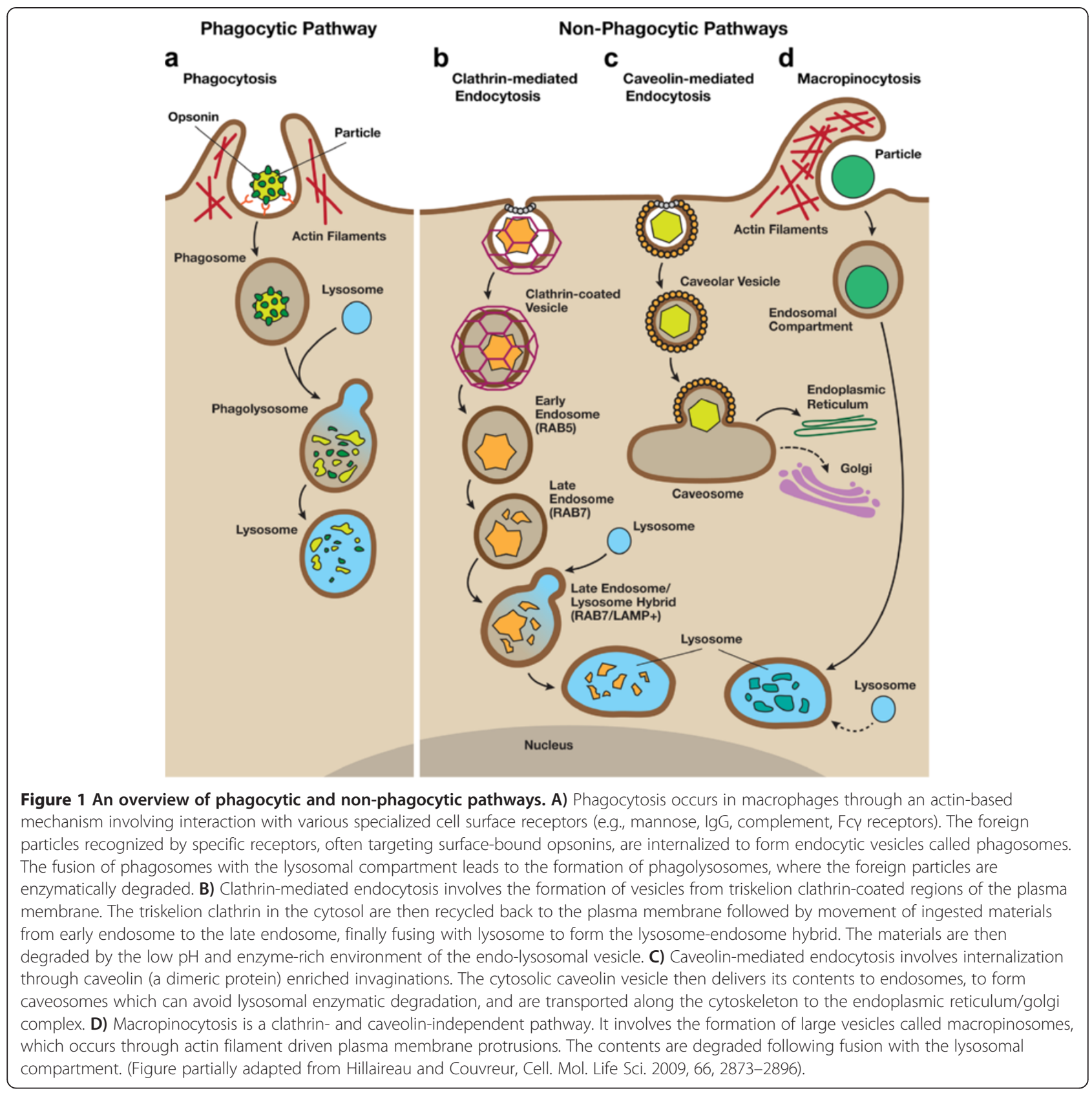

and autophagy dysfunction may play an important role in nanoparticle toxicity.

The autophagy pathway is evolutionarily conserved from yeast to mammals, with the identification of over 30 autophagy-related genes (ATG), and is regulated by several signaling cascades, e.g., mTOR and JNK $[3,22]$. Autophagy can be assessed by electron microscopy to observe autophagosomes and autolysosomes, by evaluation of the autophagy biomarker LC3-II, by use of lysosomotropic dyes, and by the use of genetically altered cells and animals, e.g., GFP-LC3 [23]. Activation of autophagy can occur in the event of stress due to starvation, depletion of growth factors, endoplasmic reticulum stress, oxidative stress and infection [22]. While autophagy is generally considered a nonselective response to these cellular stress conditions, autophagy is also reported to be homeostatic and selective in the removal of damaged organelles, ubiquitinated proteins, and pathogens [24]. For example, the autophagy adapter protein p62 binds to ubiquitinated protein aggregates and the autophagosome marker protein LC3, targeting these protein aggregates for degradation in the autolysosome $[25,26]$. There is also evidence that autophagy can selectively compartmentalize nanomaterials. 


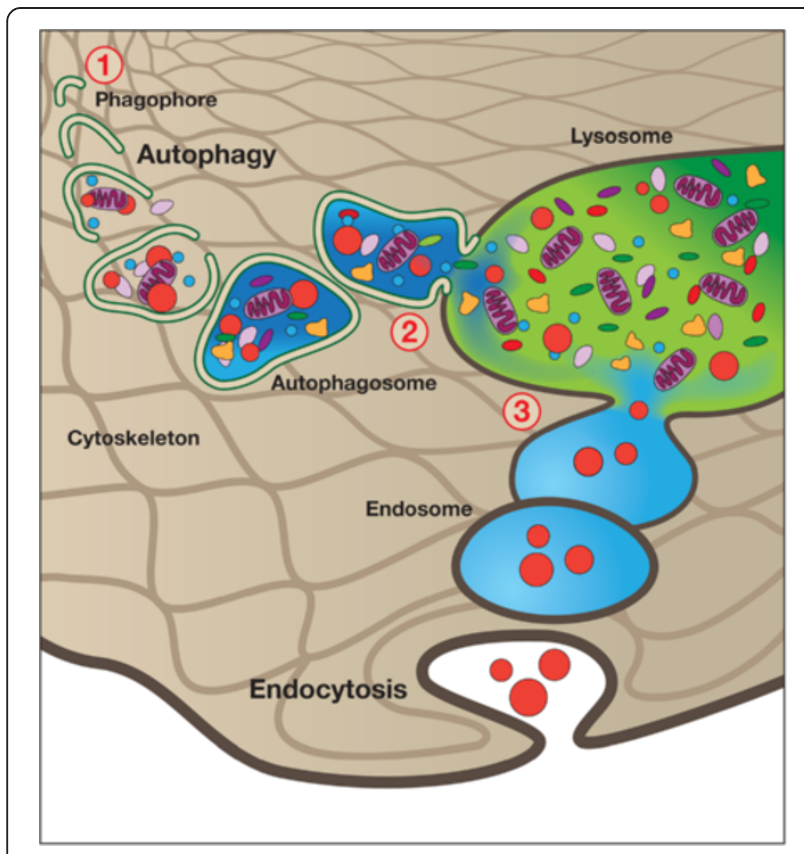

Figure 2 Autophagy. 1) During autophagy, a double layer membrane, the autophagosome, is formed that surrounds proteins and damaged organelles destined for degradation. 2) The autophagosome then merges with the lysosome, where hydrolytic enzymes in the lysosome dismantle the autophagosome contents. 3) The autophagy pathway is interconnected with the endocytosis pathways, with most endosomes eventually merging with the lysosome.

Nanomaterials have been visualized within the double membrane of autophagosomes following treatment of alveolar macrophages with carbon black nanoparticles, non-small cell lung cancer cells with EGFR-targeted gold-coated iron oxide nanoparticles, human mesenchymal stem cells with quantum dots, dendritic cells with alumina nanoparticles, and murine macrophages and human lung adenocarcinoma with silica nanoparticles [27-31]. However, as imaging techniques have been associated with artifacts, there is a need for quantitative methods to validate these findings $[8,9,11]$. A variety of nanoparticles have also been shown to induce dysfunction of the autophagy pathway [2,32], and this may be involved in their mechanism of toxicity. As will be discussed in subsequent sections, defects in the autophagy pathway have been associated with a number of pathologies in humans such as chronic infection, muscular disorders, cancer, and neurodegenerative disease [33].

\section{Lysosomal dysfunction as a toxic mechanism}

As will be discussed below, a great variety of nanomaterials have been associated with lysosomal dysfunction (see Table 1). One common form of lysosomal dysfunction that has been associated with nanomaterial treatment is lysosome membrane permeabilization (LMP).
LMP is a recognized cell death mechanism that can result in mitochondrial outer membrane permeabilization through several mechanisms, including lysosomal-iron mediated oxidative stress, and release of cathepsins and other associated lysosomal hydrolases [34] (see Figure 3). Mitochondrial permeabilization resulting from partial LMP can induce reactive oxygen species (ROS) generation and apoptosis, while massive LMP can cause cytosolic acidification and necrosis. Methods to detect LMP and lysosomal function include evaluation of the cellular distribution of $\mathrm{pH}$-dependent lysosomotropic (acidotropic) dyes (e.g., acridine orange and neutral red), lysosomotropic particles (e.g., gold-coupled albumin and fluorescencelabeled dextran) or lysosomal proteins (e.g., immunostaining of lysosomal hydrolases) [34].

As lysosomal dysfunction has been implicated in disease pathogenesis, the association of nanoparticle exposure and lysosomal dysfunction may have relevance to nanomaterialinduced toxicities, especially chronic toxicities. The lysosomal degradation pathways play a vital role in cellular homeostasis, and lysosomal dysfunction has been associated with several disease states, termed lysosomal storage disorders [33,50]. Lysosomal storage disorders, resulting from the lack of functional lysosomal enzymes or other crucial component proteins, such as $\mathrm{H}^{+}$-ATPase, manifest as degenerative diseases of the nervous and musculoskeletal systems, such as mucopolysaccharidoses and sphingolipidoses $[51,52]$. Lysosomal dysfunction resulting in an accumulation of unmetabolized substrates in the lysosome and lysosomal overload can have several possible deleterious consequences to the cell, including LMP and defects in intracellular trafficking, as well as altered intracellular signaling and gene expression [50]. Many lysosomal diseases also show evidence of autophagy dysfunction, with blockade of autophagosome and lysosome fusion, and accumulation of autophagosomes and autophagy substrates (e.g., ubiquitinated protein aggregates) [53]. Autophagy dysfunction can result from lysosomal overload or alkalization, which prevents autophagosome-lysosome fusion. Similar to lysosomal dysfunction, dysfunction of the autophagy pathway itself has also been linked to a variety of diseases [33].

\section{Lysosomal dysfunction by nanomaterials}

Lysosomotropic agents, including particles, have been known for several decades to cause lysosomal dysfunction and associated toxicities of lung, liver and kidney [4,54]. Consequently, lysosomal dysfunction may be a common outcome of nanoparticle exposure since, as described above, nanoparticles are commonly sequestered within the lysosomal compartment. Additionally, nanoparticles have properties of substances known to cause lysosomal disorders [54,55], including enzyme inhibiting ability $[56,57]$ and biopersistence. Correspondingly, many 
Table 1 A summary of nanomaterial-induced lysosomal perturbation

\begin{tabular}{|c|c|c|c|c|}
\hline Nanomaterial & $\begin{array}{l}\text { Size and charge of the } \\
\text { nanomaterial }\end{array}$ & Models & $\begin{array}{l}\text { Experimental technique used to evaluate } \\
\text { lysosomal perturbation,e.g. lysosomal } \\
\text { membrane permeabilization (LMP) }\end{array}$ & Reference \\
\hline $\begin{array}{l}\text { Multi-wall carbon } \\
\text { nanotube }\end{array}$ & $<8 \mathrm{~nm}, 20-30 \mathrm{~nm},>50 \mathrm{~nm}^{*}$ & $\begin{array}{l}3 \text { T3 fibroblast; hT } \\
\text { bronchial epithelial } \\
\text { cells; RAW } \\
\text { macrophages }\end{array}$ & $\begin{array}{l}\text { Acridine orange staining (change from lysosomal } \\
\text { red to cytosolic green fluorescence) }\end{array}$ & [35] \\
\hline $\begin{array}{l}\text { mercaptopropanoic } \\
\text { acid-coated gold } \\
\text { nanoparticles }\end{array}$ & $5 \mathrm{~nm}$; negative charge ${ }^{\#}$ & $\begin{array}{l}\text { Mytilus edulis (blue } \\
\text { mussel) }\end{array}$ & $\begin{array}{l}\text { Neutral red retention assay in the haemolymph (loss } \\
\text { of dye from the lysosomes to cytosol) }\end{array}$ & [36] \\
\hline $\begin{array}{l}\text { Titanium dioxide } \\
\text { nanoparticles }\end{array}$ & $<100 \mathrm{~nm}^{\#}$ & $\begin{array}{l}\text { Rainbow trout gonadal } \\
\text { tissue (RTG-2 cells) }\end{array}$ & $\begin{array}{l}\text { Neutral red retention assay (loss of dye from the } \\
\text { lysosomes to cytosol) }\end{array}$ & {$[37]$} \\
\hline $\begin{array}{l}\text { G5-PAMAM } \\
\text { dendrimer }\end{array}$ & $5 \mathrm{~nm}$; positive charge & $\begin{array}{l}\text { KB cells, a sub-line of } \\
\text { the human cervical } \\
\text { carcinoma HeLa cell } \\
\text { line }\end{array}$ & $\begin{array}{l}\text { Measurement of lysosomal pH using dextran- } \\
\text { fluorescein conjugate }\end{array}$ & {$[38]$} \\
\hline Glass wool & $3-7 \mu m^{*}$ & $\begin{array}{l}\text { Mytilus edulis (blue } \\
\text { mussel) }\end{array}$ & $\begin{array}{l}\text { Neutral red retention assay (loss of dye from the } \\
\text { lysosomes to cytosol) }\end{array}$ & {$[39]$} \\
\hline $\begin{array}{l}\text { Titanium dioxide } \\
\text { nanoparticles }\end{array}$ & $5 \mathrm{~nm}$; neutral ${ }^{\#}$ & L929 mouse fibroblast & Transmission electron microscopy (TEM) & {$[40]$} \\
\hline Silver nanoparticles & $25 \mathrm{~nm}$; negative charge ${ }^{\#}$ & $\begin{array}{l}\text { Crassostrea virginica } \\
\text { (Oyster) }\end{array}$ & $\begin{array}{l}\text { Neutral red retention assay (loss of dye from the } \\
\text { lysosomes to cytosol) }\end{array}$ & [41] \\
\hline $\begin{array}{l}\text { Fullerene (C60) } \\
\text { nanoparticles }\end{array}$ & $\sim 150 \mathrm{~nm}^{\#}$ & $\begin{array}{l}\text { Crassostrea virginica } \\
\text { (Oyster) }\end{array}$ & $\begin{array}{l}\text { Neutral red retention assay (loss of dye from the } \\
\text { lysosomes to cytosol) }\end{array}$ & [42] \\
\hline Silica particles & Micron scale* & $\begin{array}{l}\text { Mouse peritoneal } \\
\text { macrophages }\end{array}$ & $\begin{array}{l}\text { Acridine orange staining (change from lysosomal } \\
\text { red to cytosolic green fluorescence) and release of } \\
\text { lysosomal enzymes (Acid phosphatase and } \beta \text { - } \\
\text { glucuronidase activity) }\end{array}$ & [43] \\
\hline $\begin{array}{l}\text { TNF-bp20-K PEG } \\
\text { monomer (38 kDa) }\end{array}$ & nanoscale* & $\begin{array}{l}\text { Sprague-Dawley rats } \\
\text { (Renal cortical tubular } \\
\text { epithelium) }\end{array}$ & Histopathology evaluation (vacuolization) & [44] \\
\hline $\begin{array}{l}\text { Titanium dioxide } \\
\text { nanoparticles }\end{array}$ & $\begin{array}{l}15 \mathrm{~nm}^{*}, 461 \mathrm{~nm}(\mathrm{PBS}) ; \\
\text { negative charge }\end{array}$ & $\begin{array}{l}\text { 16HBE140-cells, human } \\
\text { bronchial epithelial } \\
\text { cells }\end{array}$ & $\begin{array}{l}\text { Acridine orange staining (change from lysosomal } \\
\text { red to cytosolic green fluorescence), } \\
\text { Immunostaining for cytosolic cathepsin B }\end{array}$ & [45] \\
\hline $\begin{array}{l}\text { Polyalkyl-sulfonated } \\
\text { C60 }\end{array}$ & nanoscale* & $\begin{array}{l}\text { Sprague-Dawley rats } \\
\text { (liver and kidney) }\end{array}$ & Histopathology, TEM & {$[46]$} \\
\hline $\begin{array}{l}\text { Zinc oxide } \\
\text { nanoparticles }\end{array}$ & $\begin{array}{l}10 \mathrm{~nm}^{*}, 229 \mathrm{~nm} \text { in PBS + } 5 \% \\
\text { mouse serum\#; negative charge } \\
\text { (in PBS + } 5 \% \text { mouse serum) }{ }^{\#}\end{array}$ & $\begin{array}{l}\text { THP-1 cells, human } \\
\text { monocytic cell line }\end{array}$ & $\begin{array}{l}\text { Acridine orange staining (change from lysosomal } \\
\text { red to cytosolic green fluorescence) }\end{array}$ & {$[47]$} \\
\hline $\begin{array}{l}\text { Titanium dioxide } \\
\text { nanoparticles }\end{array}$ & $\begin{array}{l}\text { Nanospheres } 60-200 \mathrm{~nm} \text {, Long } \\
\text { nanobelts } 15-30 \mu \mathrm{m} \text {, Short } \\
\text { nanobelts } 0.8-4 \mu \mathrm{m} \text {; slightly } \\
\text { negative }^{\#}\end{array}$ & $\begin{array}{l}\text { C57BL/6 alveolar } \\
\text { macrophages }\end{array}$ & $\begin{array}{l}\text { TEM, cytosolic cathepsin B, Acridine orange staining } \\
\text { (change from lysosomal red to cytosolic green } \\
\text { fluorescence) }\end{array}$ & [48] \\
\hline $\begin{array}{l}\text { Polystyrene } \\
\text { nanoparticles }\end{array}$ & 110 nm; positive charge $\mathrm{e}^{\#}$ & Human macrophages & $\begin{array}{l}\text { Cytosolic cathepsin B, Acridine orange staining } \\
\text { (change from lysosomal red to cytosolic green } \\
\text { fluorescence) }\end{array}$ & [49] \\
\hline
\end{tabular}

*characterized by manufacturer; ${ }^{\#}$ characterized by author.

researchers have observed nanomaterial-induced lysosomal dysfunction (see Table 1). LMP has been identified as a potential mechanism of carbon nanotube toxicity in human fibroblasts [35] and cationic polystyrene nanosphere toxicity in human macrophages [58], and in both cases LMP was associated with loss of mitochondrial membrane potential and apoptosis. In the case of the cationic polystyrene nanosphere, a "proton sponge" theory has been proposed to explain lysosomal rupture, in which the high proton buffering capacity of the particle surface amines results in excessive proton pump activity and osmotic swelling [58]. Other cationic nanoparticles, such as cationic polyamidoamine (PAMAM) dendrimers, have also been shown to induce LMP, as well as loss of mitochondrial membrane potential and apoptosis, with a similar proton sponge mechanism proposed [38].

LMP has also been noted in mussels treated with nanoscale glass wool and gold nanoparticles [36,39], as well as oysters treated with fullerene and silver nanoparticles $[41,42]$. In these cases, nanomaterials concentrated within 


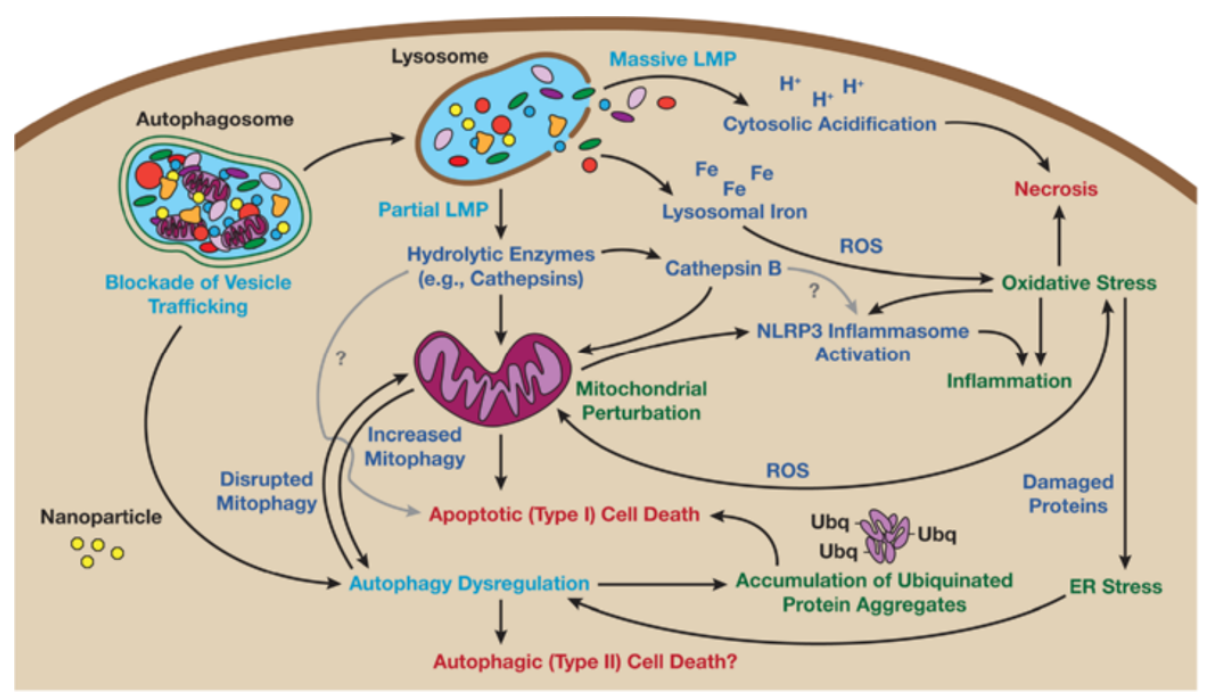

Figure 3 Mechanisms of autophagy and lysosomal dysfunction toxicity. The initiators of autophagy and lysosomal dysfunction toxicity, displayed in light blue text in the figure, include blockade of vesicle trafficking, lysosomal membrane permeabilization (LMP), and autophagy dysregulation. Nanoparticles could potentially cause autophagy dysfunction by overloading or directly damaging the lysosomal compartment, or altering the cell cytoskeleton, resulting in blockade of autophagosome-lysosome fusion. Nanoparticles could also directly affect lysosomal stability by inducing lysosomal oxidative stress, alkalization, osmotic swelling, or causing detergent-like disruption of the lysosomal membrane itself, resulting in LMP. Toxic effectors (lysosomal iron, cytosolic acidification, hydrolytic enzymes, reactive oxygen species, and the NLRP3

inflammasome) are displayed in dark blue. Conditions resulting from effector-mediated loss of homeostasis (oxidative stress, inflammation, ER stress, disrupted mitophagy, accumulation of ubiquitinated protein aggregates, and mitochondrial perturbation) are displayed in green. Finally, this loss of homeostasis can result in the cell death pathways necrosis, and Apoptotic (type I) and autophagic (type II) cell death; displayed in red (see text for details).

the lysosomal compartment of the hepatopancreas, and lysosomal destabilization was identified by evaluating cytosolic accumulation of lysosomotropic dyes or lysosomal enzymes. Lysosomal destabilization has also been proposed as a mechanism of nanoscale titanium dioxide cytotoxicity in mouse fibroblast cells [40] and human bronchial epithelial cells [45]. Lung injury induced by zinc nanoparticles in mice was also attributed to lysosomal destabilization following macrophage uptake and $\mathrm{pH}-$ dependent zinc ion dissolution [47]. This effect on lysosomal stability does not appear to be unique to nanoscale particles, as previous studies have implicated changes in lysosomal permeability and the subsequent release of lysosomal enzymes as one of the mechanisms involved in the induction of apoptosis in alveolar macrophages by silica microparticles [59]. However, there are comparative studies of nano- versus micro-scale gold nanoparticles that have suggested nanoscale particles have a much greater potency for induction of LMP [36]. Recently, inflammatory responses to particles and fibers, including silica, asbestos, high aspect ratio nanoscale titanium dioxide fibers, carbon nanotubes and amino-functionalized polystyrene nanoparticles, have been proposed to result from cathepsin B-mediated activation of the NLRP3 inflammasome following LMP $[48,49,60,61]$. Thus, in addition to providing an indirect mechanism for nanoparticle-induced ROS generation and oxidative stress through lysosomal iron release or mitochondrial damage, lysosomal dysfunction also provides a mechanism for nanoparticle-mediated inflammation (see Figure 3).

\section{Autophagy dysfunction as a toxic mechanism}

Autophagy dysfunction is defined as excessive autophagy induction or blockade of autophagy flux. Autophagy dysfunction is recognized as a potential mechanism of cell death, resulting in either apoptosis or autophagic cell death (also referred to as type II programmed cell death) [34] (see Figure 3). However, since the majority of data supports autophagy as a pro-survival pathway rather than a cell death pathway, with evidence for a direct role in cell death only coming from artificial systems in which apoptosis is chemically or genetically suppressed, the role of autophagy in "programmed cell death" is debatable [34]. Several mechanisms have been proposed to explain autophagy dysfunction-mediated apoptosis. Since agents that block autophagy flux, such as the proton pump inhibitor bafilomycin A1, also commonly predispose cells to LMP, apoptosis may in some cases be the result of LMP release of pro-apoptosis mediators such as cathepsins [62]. Recently, evidence has also been presented suggesting the autophagy proteins LC3B and ATG5 may directly activate caspase-dependent cell death through interactions with Fas and Fas-associated protein with death domain (FADD), respectively $[63,64]$. 
Additionally, a calpain truncated form of ATG5 has been shown to compete with the apoptosis suppressor protein Bcl- $\mathrm{X}_{\mathrm{L}}$, and may thereby activate apoptosis [65]. JNKmediated phosphorylation of BCL-2 may also be a common pathway for autophagy and apoptosis regulation. There is evidence that low levels of BCL-2 phosphorylation by JNK results in release of the pro-autophagy protein Beclin-1, and upon further phosphorylation there is eventual release of the pro-apoptotic factors BAX and BAK [66]. Thus, excessive JNK activation, as has been shown to occur in autophagy blockade [67], might result in release of pro-apoptosis factors through BCL-2 phosphorylation. As discussed in the following sections, autophagy flux blockade has also been associated with accumulation of ubiquitinated proteins and mitochondrial dysfunction, providing additional mechanisms for autophagy-induced apoptosis.

Similar to lysosomal dysfunction, dysfunction of the autophagy pathway has also been linked to a variety of diseases [33]. There is evidence that autophagy dysfunction plays a role in both cancer development and progression [68]. Evidence suggests that defective autophagy can lead to cancer development, possibly by allowing the accumulation of damaged organelles, such as mitochondria, that can then induce oxidative stress, inflammation and DNA damage. For example, one of the alleles of the pro-autophagy gene Beclin-1 is commonly deleted in several forms of cancer, including breast, ovarian and prostate, suggesting a tumor suppressor function for the autophagy pathway. In agreement, the monoallelic knock-out of Beclin-1 in mice enhances susceptibility to cancer $[68,69]$. There is also data to suggest that once established, autophagy may play a pro-survival role, allowing tumors to grow under nutrient deprived conditions or survive chemotherapy-induced stress. Indeed, autophagy disruptors, such as the antimalarial drug chloroquine, have been shown to synergize with chemotherapeutic agents in killing cancer cells [70]. As discussed below, some nanoparticles have also recently been shown to potentiate the cytotoxicity of chemotherapeutics by disrupting autophagy.

Defective autophagy has also been associated with Crohn's disease, a chronic inflammatory disease of the intestine, as well as with neurodegenerative conditions, such as Parkinson's and Alzheimer's disease, and may play a role in disease development [33,71-73]. Mutations in the autophagy-related genes ATG16L/IRGM and PINK1/Parkin have been linked to Crohn's and Parkinson's diseases, respectively $[33,71,74]$. In the case of Crohn's disease, disruption of autophagy's role in immunity and inflammation may be involved in disease development, while for neurodegenerative diseases such as Parkinson's and Alzheimer's disease, blockade of autophagy-mediated elimination of disease-associated proteins (e.g., amyloid beta and alpha synuclein) or damaged mitochondria may be involved [33,75-78]. Disruption in autophagosome trafficking to the lysosome has also been implicated in neurodegenerative diseases, such as mutant dynactin associated motor neuron disease and amyotrophic lateral sclerosis, as well as myopathies, such as inclusion body myopathy [33]. As exposure to airborne pollution has been associated with Alzheimer and Parkinson-like pathologies, and nanoparticles are the primary particle number and surface area component of pollution-derived particulates, we (S.T.S.) have recently postulated a relationship between nanoparticle-induced autophagy dysfunction and pollution-associated neurodegeneration [2]. In support of this hypothesis, autophagy dysfunction has recently been postulated as a mechanism of manganese nanoparticle-induced cytotoxicity in dopaminergic neuronal cells [79].

\section{Autophagy induction by nanomaterials}

Autophagy perturbation, both induction and blockade, has been reported consistently across several classes of nanomaterials and biological models (Table 2). There are several plausible mechanisms of autophagy induction by nanomaterials (Figure 4). Nanomaterials may induce autophagy through an oxidative stress mechanism [1], such as accumulation of oxidatively damaged proteins and subsequent endoplasmic reticulum stress, or mitochondrial damage [22]. The involvement of oxidative stress in induction of autophagy by nanomaterials is supported by a study in which fullerene-induced autophagy in HeLa cells was dependent upon photoactivation and suppressed by the antioxidants $\mathrm{N}$-acetyl-L-cysteine, reduced glutathione, and L-ascorbic acid [96]. Alternatively, nanomaterials may directly affect autophagy dependent signaling pathways or gene/protein expression (see Table 2). There also remains the likely possibility that autophagy induction by nanomaterials may simply be an attempt to degrade what is perceived by the cell as foreign or aberrant, similar to bacteria and other pathogens. As discussed above, nanoparticles are commonly observed within the autophagosome compartment, suggesting that activation of autophagy is a targeted attempt to sequester and degrade these materials following entrance into the cytoplasm. Cytoplasmic bacteria undergo ubiquitination, as well as colocalize with polyubiquitin complexes, and are then targeted to the autophagosome by p62 [99,100]. Recent evidence also supports ubiquitination of nanomaterials directly, or indirectly through colocalization with ubiquitinated protein aggregates, suggesting that cells may indeed select nanomaterials for autophagy through a pathway similar to invading pathogens [28,101-105].

Nanoscale neodymium oxide potently induces autophagy, as assessed by electron microscopy, in non-small 
Table 2 A summary of nanomaterial-induced autophagy perturbation

\begin{tabular}{|c|c|c|c|c|c|}
\hline Nanomaterial & $\begin{array}{l}\text { Size and charge of } \\
\text { the nanomaterial }\end{array}$ & Models & $\begin{array}{l}\text { Autophagy markers } \\
\text { examined }\end{array}$ & $\begin{array}{l}\text { Experimental } \\
\text { techniques used to } \\
\text { evaluate autophagy } \\
\text { perturbation }\end{array}$ & Reference \\
\hline Manganese nanoparticles & $30-50 \mathrm{~nm}^{*}$ & $\begin{array}{l}\text { Rat N27 dopaminergic } \\
\text { neuronal cells }\end{array}$ & $\begin{array}{l}\text { LC3 and } \\
\text { Beclin } 1\end{array}$ & $\begin{array}{l}\text { Immunoblot, GFP- } \\
\text { LC3 transfection }\end{array}$ & [79] \\
\hline Neodymium oxide nanoparticles & $80 \mathrm{~nm}^{*}$ & $\begin{array}{l}\mathrm{NCl}-\mathrm{H} 460 \text { human lung cancer } \\
\text { cells }\end{array}$ & None & $\begin{array}{l}\text { TEM, acridine orange } \\
\text { staining }\end{array}$ & {$[80]$} \\
\hline $\begin{array}{l}\text { C60 fullerene pentoxifylline dyad } \\
\text { nanoparticles }\end{array}$ & $79 \mathrm{~nm}^{\#}$ & $\begin{array}{l}\text { Mouse neuroblast neuro 2A } \\
\text { cells }\end{array}$ & LC3 & $\begin{array}{l}\text { Immunoblot and } \\
\text { TEM }\end{array}$ & [81] \\
\hline Fullerenol & $\begin{array}{l}20 \mathrm{~nm} \text {; negative } \\
\text { charge }^{\#}\end{array}$ & LLC-PK1 porcine kidney cells & LC3 & $\begin{array}{l}\text { Lysotracker assay, } \\
\text { Immunoblot, TEM }\end{array}$ & {$[32]$} \\
\hline Gold nanoparticles & $\begin{array}{l}\text { 10, 20, } 50 \mathrm{~nm} \text {; negative } \\
\text { charge }^{\#}\end{array}$ & Rat kidney (NRK) cells & LC3 & $\begin{array}{l}\text { Immunoblot, GFP- } \\
\text { LC3 transfection, TEM }\end{array}$ & {$[82]$} \\
\hline Iron oxide nanoparticles & $\begin{array}{l}115 \mathrm{~nm}^{\prime} \text {, negative } \\
\text { charge }^{\#}\end{array}$ & $\begin{array}{l}\text { A549 human lung cancer } \\
\text { cells }\end{array}$ & $\begin{array}{l}\text { LC3, ATG5, ATG12; AKT } \\
\text { signaling }\end{array}$ & Immunoblot & [83] \\
\hline $\begin{array}{l}\text { Polymeric nanoparticles } \\
\text { (Eudragit RS) }\end{array}$ & $\begin{array}{l}54 \mathrm{~nm} \text {; positive } \\
\text { charge }^{\#}\end{array}$ & $\begin{array}{l}\text { NR8383 rat alveolar } \\
\text { macrophage cell line }\end{array}$ & LC3 & $\begin{array}{l}\text { Immunoblot, TEM, } \\
\text { LC3-Immunostaining }\end{array}$ & [84] \\
\hline $\begin{array}{l}\text { EGFR-plasmonic magnetic } \\
\text { nanoparticles }\end{array}$ & $\begin{array}{l}73 \mathrm{~nm} \text {; negative } \\
\text { charge }^{\#}\end{array}$ & $\begin{array}{l}\text { Non-small cell lung cancer } \\
\text { cells }\end{array}$ & LC3 & $\begin{array}{l}\text { Immunoblot, TEM, } \\
\text { GFP-LC3 transfection }\end{array}$ & {$[31]$} \\
\hline Yttrium oxide nanoparticles & $177 \mathrm{~nm}^{\#}$ & \multirow[t]{2}{*}{ HeLa cells } & \multirow[t]{2}{*}{ LC3 } & \multirow{2}{*}{$\begin{array}{l}\text { Immunoblot, TEM, } \\
\text { GFP-LC3 transfection }\end{array}$} & \multirow[t]{2}{*}{ [85] } \\
\hline Ytterbium oxide nanoparticles & $279 \mathrm{~nm}^{\#}$ & & & & \\
\hline Fullerene C60 nanoparticles & $\begin{array}{l}\text { 50-100 nm; negative } \\
\text { charge }^{\#}\end{array}$ & $\begin{array}{l}\text { MCF-7 human breast cancer } \\
\text { cell line }\end{array}$ & LC3 & $\begin{array}{l}\text { Immunoblot, GFP- } \\
\text { LC3 transfection }\end{array}$ & {$[86]$} \\
\hline $\begin{array}{l}\text { Uncoated, ultrasmall } \\
\text { superparamagnetic iron oxide } \\
\text { (USPIO) nanoparticles }\end{array}$ & $\begin{array}{l}8 \mathrm{~nm} \text {; positive } \\
\text { charge* }\end{array}$ & \multirow[t]{3}{*}{$\begin{array}{l}\text { HCEC Human brain } \\
\text { endothelial cells }\end{array}$} & \multirow[t]{3}{*}{ LC3 } & \multirow[t]{3}{*}{ Immunoblot, TEM } & \multirow[t]{3}{*}{ [87] } \\
\hline Titanium dioxide nanoparticles & $\begin{array}{l}21 \mathrm{~nm} \text {; negative } \\
\text { charge }^{*}\end{array}$ & & & & \\
\hline Silica nanoparticles & $\begin{array}{l}25,50 \mathrm{~nm} \text {; negative } \\
\text { charge* }^{*}\end{array}$ & & & & \\
\hline Cadmium selenide quantum dot & $5.1 \mathrm{~nm}^{\#}$ & \multirow[t]{2}{*}{ LLC-PK1 porcine kidney cells } & \multirow[t]{2}{*}{ LC3 } & \multirow{2}{*}{$\begin{array}{l}\text { Immunoblot, TEM, } \\
\text { Lysotracker assay }\end{array}$} & \multirow[t]{2}{*}{ [88] } \\
\hline $\begin{array}{l}\text { Indium gallium phosphide } \\
\text { quantum dot }\end{array}$ & $3.7 \mathrm{~nm}^{\#}$ & & & & \\
\hline PAMAN Dendrimer & $\begin{array}{l}\text { Several different } \\
\text { generations (varying in } \\
\text { sizes and charge)* }\end{array}$ & $\begin{array}{l}\text { A549 human lung cancer } \\
\text { cells; Balblc mice }\end{array}$ & $\begin{array}{l}\text { LC3, AKT } \\
\text { signaling }\end{array}$ & $\begin{array}{l}\text { Immunoblot, TEM, } \\
\text { GFP-LC3 transfection }\end{array}$ & [89] \\
\hline $\begin{array}{l}\text { Silica nanoparticles } \\
\text { (spheres, worms, cylinders) }\end{array}$ & Several $\left.\right|^{\#}$ & $\begin{array}{l}\text { A549 human lung cancer } \\
\text { cells, RAW } 264.7 \text { mouse } \\
\text { macrophages }\end{array}$ & LC3 & Immunoblot, TEM & [27] \\
\hline Fullerene C60/70 nanoparticles & $100 \mathrm{~nm}^{\#}$ & Rat C6 glioma cell line & None & $\begin{array}{l}\text { Acridine orange } \\
\text { staining }\end{array}$ & [90] \\
\hline $\begin{array}{l}\text { Iron core with gold shell } \\
\text { nanoparticles }\end{array}$ & $10 \mathrm{~nm}^{\#}$ & $\begin{array}{l}\text { OEMC1 human oral cancer } \\
\text { cell line }\end{array}$ & LC3 & $\begin{array}{l}\text { Immunoblot, TEM, } \\
\text { LC3 Immunostaining }\end{array}$ & [91] \\
\hline Titanium dioxide nanoparticles & $<25 \mathrm{~nm}^{*}$ & $\begin{array}{l}\text { HT29 human colon cancer } \\
\text { cell line }\end{array}$ & None & GFP-LC3 transfection & [92] \\
\hline Palladium nanoparticles & 5-10 nm & $\begin{array}{l}\text { Peripheral blood } \\
\text { mononuclear cells (PBMC) }\end{array}$ & LC3 & TEM & [93] \\
\hline $\begin{array}{l}\text { Single walled carbon nanotube- } \\
\text { carboxylic acid }\end{array}$ & nanoscale* & $\begin{array}{l}\text { A549 human lung cancer cell } \\
\text { line/Balb/c mice }\end{array}$ & $\begin{array}{l}\text { LC3, AKT } \\
\text { signaling }\end{array}$ & $\begin{array}{l}\text { Immunoblot, TEM, } \\
\text { ATG6 siRNA } \\
\text { transfection }\end{array}$ & [94] \\
\hline Gold nanoparticles & $\begin{array}{l}22 \mathrm{~nm} \text {; negative } \\
\text { charge }^{\#}\end{array}$ & $\begin{array}{l}\text { MRC-5 human lung fibroblast } \\
\text { cells }\end{array}$ & LC3, ATG7 & Immunoblot, TEM & {$[95]$} \\
\hline Fullerene C60 nanocrystals & $20-100 \mathrm{~nm}^{\#}$ & $\begin{array}{l}\text { MCF-7 human breast cancer } \\
\text { cell line, HeLa human cervical } \\
\text { cancer cell line }\end{array}$ & LC3 & $\begin{array}{l}\text { Immunoblot, TEM, } \\
\text { GFP-LC3 transfection }\end{array}$ & {$[96]$} \\
\hline
\end{tabular}


Table 2 A summary of nanomaterial-induced autophagy perturbation (Continued)

\begin{tabular}{|c|c|c|c|c|c|}
\hline $\begin{array}{l}\text { Samarium oxide; Europium } \\
\text { oxide; Gadolinium oxide; } \\
\text { Terbium oxide nanoparticles }\end{array}$ & $50 \mathrm{~nm}^{\#}$ & $\begin{array}{l}\text { HeLa human cervical cancer } \\
\text { cell line }\end{array}$ & LC3 & $\begin{array}{l}\text { Immunoblot, TEM, } \\
\text { GFP-LC3 transfection }\end{array}$ & [97] \\
\hline Fullerenol nanoparticles & $7.1 \mathrm{~nm}^{\#}$ & $\begin{array}{l}\text { HUVEC human umbilical vein } \\
\text { endothelial cell line }\end{array}$ & LC3 & Immunoblot, TEM & [98] \\
\hline Quantum dots & nanoscale* & $\begin{array}{l}\text { Human mesenchymal stem } \\
\text { cells }\end{array}$ & LC3 & $\begin{array}{l}\text { LC3 immunostaining, } \\
\text { TEM }\end{array}$ & [30] \\
\hline Alpha alumina nanoparticles & $60 \mathrm{~nm}^{\#}$ & Dendritic cells & LC3 & $\begin{array}{l}\text { LC3 immunostaining, } \\
\text { Immunoblot, TEM }\end{array}$ & [28] \\
\hline
\end{tabular}

*characterized by manufacturer; ${ }^{\#}$ characterized by author.

cell lung cancer NCI-H460 cells [80]. Induction of autophagy has also been observed following treatment with several other rare earth oxide nanocrystals, such as gadolinium oxide, in HeLa cells [97]. Induction of autophagy in human fibroblasts by gold nanoparticles, currently in development for drug delivery applications [106], was associated with upregulation of autophagy proteins LC3 and ATG7 [95]. Quantum dots, currently under development for a broad range of biomedical imaging applications, have also been shown to induce autophagy in a variety of cell lines, including porcine kidney cells (Figure 5) and human mesenchymal stem cells $[30,88]$. As the underlying composition (e.g., CdSe, InGaP) and surface chemistries (e.g., protein coated, silica coated, PEGylated) of the quantum dots used in these studies varied substantially, it would suggest that the commonality of nanoscale size was a significant factor in eliciting this common autophagic response. Consistent with this assumption, autophagy was not induced by quantum dots that had a tendency to aggregate to micro-scale particles intracellularly [30]. Nanoscale size dependence was also noted for neodymium oxide nanoparticle autophagy-induction [80], with larger particles having reduced activity.

Recently, it has been reported that cationic PAMAM dendrimers and carboxylated carbon nanotubes could induce autophagosome accumulation in human lung adenocarcinoma cells $[89,94]$. Cytotoxicity associated with dendrimer or carbon nanotube treatment of the lung cancer cells was blocked by cotreatment with the autophagy inhibitor 3-methyladenine (3-MA) or knockdown of the autophagy gene ATG6, suggesting involvement of the autophagy pathway in cytotoxicity. Data further suggested that autophagy induction by both the cationic dendrimer and carbon nanotube was the result of inhibition of mTOR signaling. However, the possibility of autophagy flux blockade in concert with autophagy induction through the mTOR pathway was not

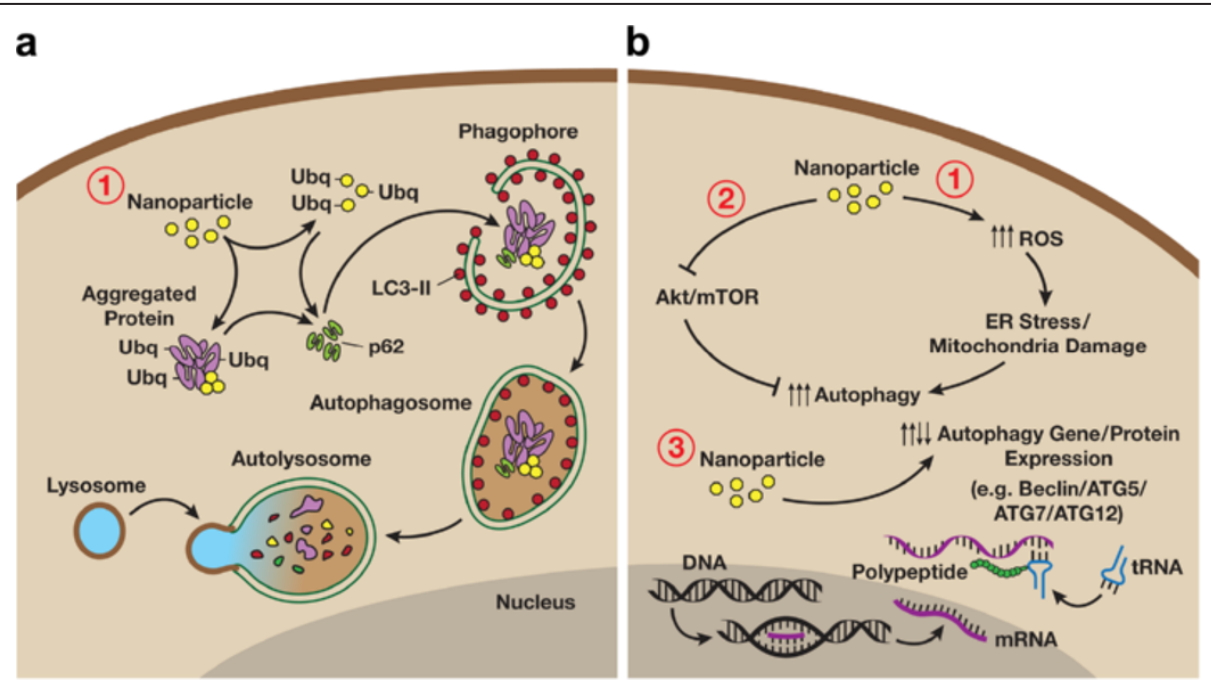

Figure 4 Nanoparticle-induced autophagy. A) Recent evidence supporting ubiquitination of nanomaterials directly, or indirectly through colocalization with protein aggregates, suggests that cells may select nanomaterials for autophagy through a p62-LC3 II pathway similar to invading pathogens (see text). B) Data also supports nanomaterial-induced alteration of autophagy signaling pathways, including: 1) induction of oxidative stress-dependent signaling (e.g., ER stress, mitochondrial damage), 2) suppression of Akt-mTOR signaling, and $\mathbf{3}$ ) alteration of autophagy related gene/protein expression. 

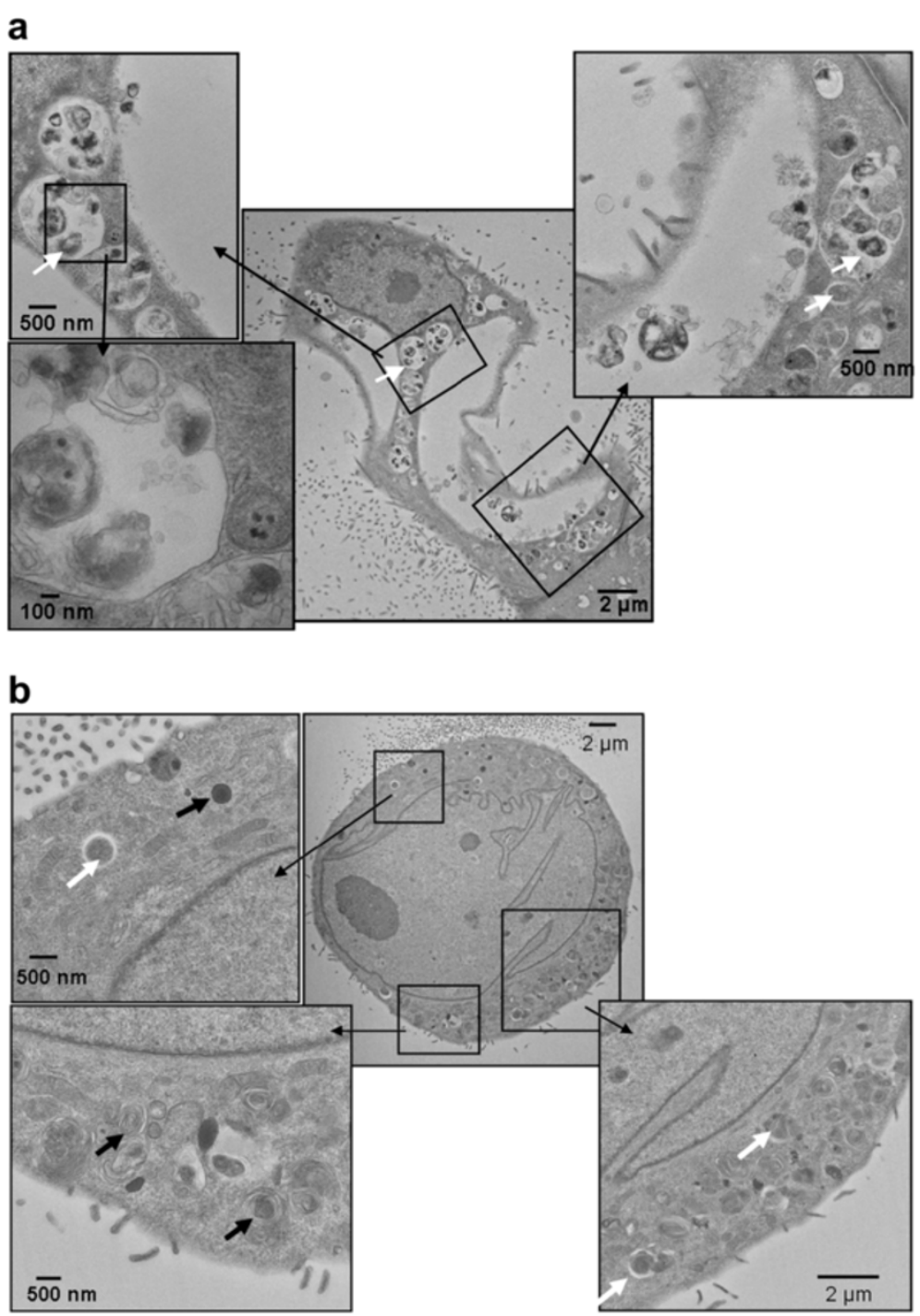

Figure 5 Transmission electron micrographs detailing autophagic vacuoles. Porcine kidney cells (LLC-PK1) were treated for $24 \mathrm{~h}$ with either (A) $10 \mathrm{nM}$ CdSe or (B) $100 \mathrm{nM}$ InGaP quantum dots. The white arrows indicate autophagic vacuoles containing cellular debris. The black arrows indicate lysosomal remnants, consisting of multilamellar vacuoles and electron-dense deposits. (Stern ST, et al, Induction of Autophagy in Porcine Kidney Cells by Quantum Dots: A Common Cellular Response to Nanomaterials? Tox. Sci. 2008, 106(1), 140-152, by permission of Oxford University Press.).

evaluated. Treatment of mice with cationic PAMAM dendrimers or carbon nanotubes by intratracheal instillation resulted in lung inflammation, as determined by lung wet/dry ratios, immune cell infiltration, and histology. Consistent with the in vitro findings, autophagosome accumulation was also observed in the lung tissue of mice treated with the carboxylated carbon nanotubes. Also consistent with the in vitro findings, cationic dendrimer and carbon nanotube-induced lung inflammation, and associated animal death, could be prevented by cotreatment with 3-MA. In further support of cationic PAMAM dendrimer interaction with the autophagy pathway, liver lesions observed in mice treated intraperitoneally (i.p.) with cationic PAMAM dendrimers in a separate study had histological features typical of lysosomal disorders observed with polycationic drugs, including vacuolization $[54,107,108]$.

\section{Autophagy blockade by nanomaterials}

In the majority of the studies (Table 2), autophagosome accumulation induced by nanomaterial treatment was associated with cell death. As mentioned above, there is scant evidence of autophagy as an actual effector of cell death, and cytotoxicity resulting from blockade of autophagy's pro-survival mechanisms would appear the more likely scenario. Since blockade of autophagy flux and 
autophagy induction can both lead to autophagosome accumulation [23], and the possibility of autophagy blockade was most often not investigated, the mechanism of nanomaterial-induced autophagy accumulation in many cases is uncertain. In cases where autophagy flux has been evaluated, disrupted or blocked autophagy flux is more often seen upon exposure to nanomaterials. For example, fullerene, the fullerene derivative fullerenol, and gold nanoparticles have been shown to block autophagy flux in various cell lines $[32,82,86]$. In renal proximal tubule cells, blockade of autophagy flux by fullerenol, as measured by increased autophagosome marker LC3-II and autophagy flux marker p62, was associated with mitochondrial depolarization and disruption of the actin cytoskeleton [32]. In support of the in vivo relevance of these findings, an acute toxicity study of a water soluble polyalkylsulfonated fullerene in rats identified a lysosomal overload nephropathy that is consistent with blockade of lysosomal trafficking [46].

There is a substantial body of literature linking nanomaterial-induced autophagy dysfunction with mitochondrial damage $[27,32,79,83,84,91]$. Disruption of the autophagy pathway by genetic knockout has also been associated with accumulation of dysfunctional mitochondria, as well as accumulation of ROS, thus providing a potential link between nanomaterial-induced autophagy blockade and oxidative stress [109]. Nanomaterialinduced autophagy blockade may also be a mechanism of nanomaterial-associated inflammation, as there is evidence that autophagy plays an important role in negatively regulating the NLRP3 inflammasome [110]. Autophagy blockade may result in mitochondrial dysfunction by preventing removal of damaged mitochondria that are normally degraded through the autophagy pathway [111]. Postulated to be a mechanism to eliminate damaged mitochondria, there is also evidence that mitochondrial depolarization actually precedes autophagy induction [112]. Thus, it is conceivable that a combination of autophagy induction and autophagy blockade, as might be expected with nanoparticles, could result in an increased number of depolarized dysfunctional mitochondria that cannot be cleared as a result of the impaired autophagy flux. Indeed, the combination of autophagy induction, by Akt inhibition, and autophagy flux blockade, by chloroquine treatment, results in accumulation of abnormal, depolarized mitochondria and ROS in human prostate cancer cells [113]. Similarly, simultaneous starvation-induced autophagy and autophagy flux blockade, by treatment with the proton pump inhibitor bafilomycin A1, also results in mitochondrial depolarization in cervical cancer cells [114].

The relationship between nanomaterial-induced autophagy blockade and mitochondrial dysfunction is intriguing [32], as blockade of autophagy flux with concomitant mitochondrial dysfunction has also been observed in alveolar macrophages from smokers [29]. Mitochondrial dysfunction in smokers' alveolar macrophages could be reproduced by treatment of alveolar macrophages from non-smokers with bafilomycin A1, a proton pump inhibitor that is also known to block autophagy flux by inhibition of the lysosomal proton pump [29]. Autophagy blockade and mitochondrial dysfunction in smokers' macrophages were also reproduced by treatment of alveolar macrophages from non-smokers with cigarette smoke extract or, most importantly, nanoscale carbon black, a component of cigarette smoke, thus implicating nanoscale particulates in this process [29]. This is not surprising, as studies have observed autophagosome accumulation in human umbilical vein endothelial cells treated with nanoscale carbon black [115]. Recently, cytotoxicity associated with autophagosome accumulation and mitochondrial damage was also observed following treatment of rat alveolar macrophages with Eudragit ${ }^{\circledR}$ RS nanoparticles [84].

The autophagy blockade observed in smokers' alveolar macrophages was associated with reduced pathogen phagocytosis and reduced delivery of phagocytosed pathogens to the lysosome, which might explain the increased susceptibility of smokers to bacterial infection [29]. Previous studies have shown nanoscale particulates to have a greater potency than larger particles of the same material in retarding lung particle clearance, resulting in lung particle overload [116]. This could conceivably be in part due to a greater blockade of the autophagy pathway by the nanoscale particles, as clearance of pathogens and other immune functions, including regulation of proinflammatory responses, have been attributed to the autophagy pathway [117].

Another interesting phenomenon associated with autophagy blockade in the alveolar macrophage from smokers was accumulation of polyubiquitinated protein complexes [29]. This accumulation of ubiquitinated proteins has also been observed previously in human vascular endothelial cells treated with fullerenes, and was also associated with autophagy dysfunction [98]. The disruption in clearance of polyubiquitinated proteins upon autophagy dysfunction is further evidence that autophagy, in addition to the proteasome, is involved in degradation of ubiquitin-targeted proteins [118].

\section{Mechanisms of lysosomal dysfunction and autophagy blockade by nanomaterials}

There are many plausible explanations for nanoparticleinduced lysosomal dysfunction (Figure 3). In addition to the "proton sponge" hypothesis of LMP for cationic nanoparticles described above, involving osmotic swelling and membrane rupture, another direct mechanism that might account for nanoparticle-induced LMP is the generation of ROS, as studies have shown that reactive 
oxygen species can induce LMP in cells in culture [119]. This may be a likely mechanism, as many nanoparticles can induce ROS, and the oxidative stress paradigm of nanoparticle-induced toxicity is by far the most accepted [1]. Agents that alkalinize the lysosome, such as the proton pump inhibitor bafilomycin A1, also commonly predispose cells to LMP [62]. Supportive of an alkalization mechanism, gold nanoparticles have recently been shown to increase lysosomal $\mathrm{pH}$ in rat kidney cells, causing lysosomal dysfunction [82]. Disruption of lysosomal trafficking has also been shown to increase LMP susceptibility. For example, agents that block lysosomal trafficking by disruption of the cytoskeleton, such as vinca alkaloids, also induce LMP and cathepsin-dependent apoptosis [120]. Likewise, mutation of the LYST gene that encodes a lysosomal trafficking regulator, seen in Chediak-Higashi Syndrome, results in dysfunctional lysosomes with a greater propensity toward LMP [121]. Recently, our laboratory found that fullerenol treatment of kidney cells resulted in blockade of autophagy flux, potentially by disruption of actin cytoskeleton-mediated lysosome trafficking [32].

Disruption of lysosomal trafficking is a principle mechanism for blockade of autophagy flux, resulting in accumulation of autophagic and lysosomal vacuoles. There are several plausible mechanisms by which nanoscale particulates might disrupt autophagy and lysosomal trafficking (Figure 3). Lysosomal overload by particulates has been proposed as a mechanism for blockade of autophagy flux by cigarette smoke in alveolar macrophages [29]. The overload of alveolar macrophage lysosomes with indigestible material, such as smoke particulates and asbestos nanofibers, has been shown to disrupt lysosomal fusion with other cellular compartments, resulting in vacuole accumulation [122]. This would suggest that biopersistent nanomaterials are of greater concern. Indeed, biopersistent gold nanoparticles have been shown to accumulate in the lysosome, blocking autophagosome-lysosome fusion fusion and lysosomal degradation [82]. This association between biopersistent materials and lysosomal dysfunction, presenting as intracellular vacuolation, has been observed previously in the kidneys of Sprague Dawley rats treated with polyethylene-glycol conjugated proteins, and in the liver of humans receiving polyvinyl pyrrolidone as a plasma expander [44,123].

Another likely mechanism of autophagy blockade is disruption of the cytoskeleton upon which the autophagy and lysosomal compartments rely for cellular trafficking. Agents that disrupt the microtubular cytoskeleton, such as vinblastine, cause blockade of autophagy flux during both selective, basal autophagy and nonselective, starvation-induced autophagy by preventing autophagosome-lysosome fusion [124-127]. By contrast, the actin cytoskeleton appears to be specifically involved in selective, quality control autophagy in both yeast $[128,129]$ and mammalian cells [130]. During quality control autophagy in mammalian cells, which is responsible for removal of protein aggregates and damaged mitochondria, the ubiquitin binding deacetylase, histone deacetylase- 6 , has recently been shown to regulate autophagosome-lysosome fusion by actin remodeling [130]. Furthermore, latrunculin A, an agent that disrupts actin polymerization, blocks autophagosome-lysosome fusion during selective, basal autophagy [130]. As the studies described above detailing nanomaterial-induced autophagy blockade appear associated with disruption in mitochondrial and protein quality control autophagy, the actin cytoskeleton represents a plausible nanomaterial target.

A survey of protein binding of cellular extracts to silicon dioxide, titanium dioxide, and polystyrene nanoparticles and microparticles, with varying surface chemistries, found actin to be one of the most commonly bound proteins [131]. A similar actin binding tendency has been observed in our laboratory upon incubation of gold nanoparticles with human serum (unpublished data), even though actin is of low abundance in serum. In addition, our laboratory also has preliminary data that certain nanomaterials may alter actin polymerization (unpublished data). In further support of actin as a potential target of nanomaterial-induced autophagy dysfunction, cationic dendrimers have been shown to bind actin and inhibit actin polymerization in vitro [132], and induce autophagy dysfunction both in vitro and in vivo [89]. Treatment of human aortic endothelial cells and primary human dermal fibroblasts with carbon nanotubes [133] and gold nanoparticles [134], respectively, also results in disruption of the actin cytoskeleton, and both materials have also been shown to induce autophagy dysfunction in separate studies [94,95]. Additionally, researchers have shown that treatment of human umbilical vein endothelial cells with nanoscale iron oxide particles results in disruption of the actin and microtubule cytoskeletons, and coincident autophagy dysfunction [135].

\section{Autophagy and lysosomal dysfunction as a therapeutic mechanism}

The interaction of nanomaterials with the autophagy and lysosomal pathways, and resulting dysfunction, is not necessarily always a disadvantageous scenario. As described above, LMP has been identified as a potential mechanism of cationic dendrimer cytotoxicity, but this LMP induction may also have benefits for drug delivery. Dendrimers are currently under development for a variety of drug delivery and imaging applications [136], and cationic dendrimer-induced LMP, as well as that of other cationic nanoparticles, has been used to enable 
lysosomal escape for cellular delivery of drugs, including gene therapies $[137,138]$.

Many novel nanomedicine therapeutics are also under development utilizing autophagy dysfunction as a therapeutic mechanism. For example, a novel therapeutic vaccine is presently under development that utilizes alumina nanoparticles to transport bound antigen to autophagosomes of dendritic cells in an apparent p62-mediated fashion, block lysosomal degradation, and elicit a potent T-cell anti-tumor response [28]. Iron oxide and iron-coated gold nanoparticles currently being developed as potential therapeutics have been shown to selectively kill lung epithelial and oral squamous carcinoma cells, respectively, by an apparent autophagy-dependent mechanism [83,91].

As mentioned previously, autophagy disrupters are currently being evaluated in clinical trials for their ability to synergize with existing cancer therapies [70]. In order to identify new autophagy modulating agents for use as therapeutics, as well as evaluate responses to these agents, there is a need for methods to monitor autophagy. Since nanomaterials have been shown to interact with the autophagy pathway, they have been proposed as new tools to monitor autophagy [139]. An example of the use of a nanoparticlebased autophagy monitoring system has been described by Choi et al [140]. In this autophagy flux monitoring system, a fluorescent-peptide construct on the surface of a lysosomotropic polymeric nanoparticle is cleaved to a fluorescent form by the autophagy flux-dependent protease Atg4.

Recently, Lee et al. have demonstrated the ability of a water-dispersed neodymium fullerene derivative to synergize with doxorubicin to kill drug resistant MCF-7 human breast cancer cells [86]. The mechanism behind this synergy was shown to be dependent upon autophagy, as fullerene treatment resulted in dramatic autophagosome accumulation and the autophagy inhibitor 3-methyladenine blocked both autophagosome accumulation and drug synergy. However, treatment with the autophagy inducer rapamycin, an inhibitor of mTOR, had the opposite effect, actually antagonizing doxorubicin cytotoxicity. The authors concluded that blockade of autophagy flux and resulting futile autophagy, possibly due to particle overload and disruption of autophagosome-lysosome fusion, was the mechanism underlying the observed synergy. Fullerene interaction with the autophagy pathway is also currently being explored for the amelioration of amyloid-beta toxicity and treatment of Alzheimer's disease [81]. Obviously, there is a need to understand the balance between the potential benefits of lysosomal dysfunctions for therapeutic purposes and potential harmful effects to the cell.

\section{Conclusion}

The continued expansion of the field of nanotechnology requires a thorough understanding of the potential mechanisms of nanomaterial toxicity for proper safety assessment and identification of exposure biomarkers. With increasing research into nanomaterial safety, details on the biological effects of nanomaterials have begun to emerge. Researchers should be aware that nanomaterials can have detrimental effects on the autophagy and lysosomal pathways, resulting in toxicological consequences. Overall, expanding knowledge of the implications and biological significance of autophagy and lysosomal dysfunction has tremendous potential to aid in our understanding of nanotechnology risks, and design of safer nanomaterials and nanomedicines.

\section{Competing interests}

The authors have no competing interests.

\section{Authors' contributions}

STS and PPA performed literature reviews and wrote manuscript. R.M.C. provided critical review and assisted with manuscript generation. All authors read and approved the final manuscript.

\section{Acknowledgements}

The authors wish to thank David Parmiter, SAIC-Frederick, Inc. for electron microscopy and Allen Kane, SAIC-Frederick, Inc., for graphic illustrations. This project has been funded in whole or in part with federal funds from the National Cancer Institute, National Institutes of Health, under Contract No. HHSN261200800001E. The content of this publication does not necessarily reflect the views or policies of the Department of Health and Human Services, nor does mention of trade names, commercial products, or organizations imply endorsement by the U.S. Government.

Received: 27 February 2012 Accepted: 14 June 2012

Published: 14 June 2012

References

1. Li N, Xia T, Nel AE: The role of oxidative stress in ambient particulate matter-induced lung diseases and its implications in the toxicity of engineered nanoparticles. Free Radic Biol Med 2008, 44:1689-1699.

2. Stern ST, Johnson DN: Role for nanomaterial-autophagy interaction in neurodegenerative disease. Autophagy 2008, 4:1097-1100.

3. Klionsky DJ: Autophagy: from phenomenology to molecular understanding in less than a decade. Nat Rev Mol Cell Biol 2007, 8: 931-937.

4. De Duve C, De Barsy T, Poole B, Trouet A, Tulkens P, Van Hoof F: Commentary. Lysosomotropic agents. Biochem Pharmacol 1974, 23: 2495-2531.

5. Hillaireau H, Couvreur P: Nanocarriers' entry into the cell: relevance to drug delivery. Cell Mol Life Sci 2009, 66:2873-2896.

6. Sahay G, Alakhova DY, Kabanov AV: Endocytosis of nanomedicines. J Control Release 2010, 145:182-195.

7. Zaki NM, Tirelli N: Gateways for the intracellular access of nanocarriers: a review of receptor-mediated endocytosis mechanisms and of strategies in receptor targeting. Expert Opin Drug Deliv 2010, 7:895-913.

8. Brandenberger C, Clift MJ, Vanhecke D, Muhlfeld C, Stone V, Gehr P, RothenRutishauser B: Intracellular imaging of nanoparticles: is it an elemental mistake to believe what you see?. Particle and fibre toxicology 2010, 7:15.

9. Seib FP, Jones AT, Duncan R: Establishment of subcellular fractionation techniques to monitor the intracellular fate of polymer therapeutics I. Differential centrifugation fractionation B16F10 cells and use to study the intracellular fate of HPMA copolymer - doxorubicin. J Drug Target 2006, 14:375-390.

10. Vercauteren D, Vandenbroucke RE, Jones AT, Rejman J, Demeester J, De Smedt SC, Sanders NN, Braeckmans K: The use of inhibitors to study endocytic pathways of gene carriers: optimization and pitfalls. Mol Ther 2010, 18:561-569.

11. Manunta M, Izzo L, Duncan R, Jones AT: Establishment of subcellular fractionation techniques to monitor the intracellular fate of polymer therapeutics II. Identification of endosomal and lysosomal 
compartments in HepG2 cells combining single-step subcellular fractionation with fluorescent imaging. J Drug Target 2007, 15:37-50.

12. Conner SD, Schmid SL: Regulated portals of entry into the cell. Nature $2003,422: 37-44$

13. Aderem A, Underhill DM: Mechanisms of phagocytosis in macrophages. Annu Rev Immunol 1999, 17:593-623.

14. Immordino ML, Dosio F, Cattel L: Stealth liposomes: review of the basic science, rationale, and clinical applications, existing and potential. Int J Nanomedicine 2006, 1:297-315.

15. Vonarbourg A, Passirani C, Saulnier P, Benoit JP: Parameters influencing the stealthiness of colloidal drug delivery systems. Biomaterials 2006 27:4356-4373.

16. Bareford LM, Swaan PW: Endocytic mechanisms for targeted drug delivery. Adv Drug Deliv Rev 2007, 59:748-758.

17. Marsh M, Helenius A: Virus entry: open sesame. Cell 2006, 124:729-740.

18. Pelkmans L, Kartenbeck J, Helenius A: Caveolar endocytosis of simian virus 40 reveals a new two-step vesicular-transport pathway to the ER. Nat Cell Biol 2001, 3:473-483

19. Dauty E, Remy JS, Zuber G, Behr JP: Intracellular delivery of nanometric DNA particles via the folate receptor. Bioconjug Chem 2002, 13:831-839.

20. Thurn KT, Arora H, Paunesku T, Wu A, Brown EM, Doty C, Kremer J, Woloschak G: Endocytosis of titanium dioxide nanoparticles in prostate cancer PC-3 M cells. Nanomedicine 2011, 7:123-130.

21. De Duve C: The lysosome. Sci Am 1963, 208:64-72.

22. He C, Klionsky DJ: Regulation mechanisms and signaling pathways of autophagy. Annu Rev Genet 2009, 43:67-93.

23. Barth S, Glick D, Macleod KF: Autophagy: assays and artifacts. J Pathol 2010, 221:117-124

24. Komatsu M, Ichimura Y: Selective autophagy regulates various cellular functions. Genes Cells 2010, 15:923-933.

25. Ichimura $Y$, Komatsu M: Selective degradation of $p 62$ by autophagy. Semin Immunopathol 2010, 32:431-436.

26. Ni HM, Bockus A, Wozniak AL, Jones K, Weinman S, Yin XM, Ding WX: Dissecting the dynamic turnover of GFP-LC3 in the autolysosome. Autophagy 2011, 7:188-204.

27. Herd HL, Malugin A, Ghandehari $\mathrm{H}$ : Silica nanoconstruct cellular toleration threshold in vitro. J Control Release 2011, 153:40-48.

28. Li H, Li Y, Jiao J, Hu HM: Alpha-alumina nanoparticles induce efficient autophagy-dependent cross-presentation and potent antitumour response. Nat Nanotechnol 2011, 6:645-650

29. Monick MM, Powers LS, Walters K, Lovan N, Zhang M, Gerke A, Hansdottir S, Hunninghake GW: Identification of an autophagy defect in smokers' alveolar macrophages. J Immunol 2010, 185:5425-5435.

30. Seleverstov O, Zabirnyk O, Zscharnack M, Bulavina L, Nowicki M, Heinrich JM, Yezhelyev M, Emmrich F, O'Regan R, Bader A: Quantum dots for human mesenchymal stem cells labeling. A size-dependent autophagy activation. Nano Lett 2006, 6:2826-2832.

31. Yokoyama T, Tam J, Kuroda S, Scott AW, Aaron J, Larson T, Shanker M, Correa AM, Kondo S, Roth JA, Sokolov K, Ramesh R: EGFR-targeted hybrid plasmonic magnetic nanoparticles synergistically induce autophagy and apoptosis in non-small cell lung cancer cells. PLoS One 2011, 6:e25507.

32. Johnson-Lyles DN, Peifley K, Lockett S, Neun BW, Hansen M, Clogston J, Stern ST, McNeil SE: Fullerenol cytotoxicity in kidney cells is associated with cytoskeleton disruption, autophagic vacuole accumulation, and mitochondrial dysfunction. Toxicol Appl Pharmacol 2010, 248:249-258.

33. Ravikumar B, Sarkar S, Davies JE, Futter M, Garcia-Arencibia M, GreenThompson ZW, Jimenez-Sanchez M, Korolchuk VI, Lichtenberg M, Luo S, Massey DC, Menzies FM, Moreau K, Narayanan U, Renna M, Siddiqi FH, Underwood BR, Winslow AR, Rubinsztein DC: Regulation of mammalian autophagy in physiology and pathophysiology. Physiol Rev 2010, 90: 1383-1435.

34. Kroemer G, Jaattela M: Lysosomes and autophagy in cell death control. Nat Rev Cancer 2005, 5:886-897.

35. Sohaebuddin SK, Thevenot PT, Baker D, Eaton JW, Tang L: Nanomaterial cytotoxicity is composition, size, and cell type dependent. Particle and fibre toxicology 2010, 7:22.

36. Tedesco S, Doyle H, Blasco J, Redmond G, Sheehan D: Oxidative stress and toxicity of gold nanoparticles in Mytilus edulis. Aquat Toxicol 2010 100:178-186.
37. Vevers WF, Jha AN: Genotoxic and cytotoxic potential of titanium dioxide (TiO2) nanoparticles on fish cells in vitro. Ecotoxicology 2008, 17:410-420.

38. Thomas TP, Majoros I, Kotlyar A, Mullen D, Holl MM, Baker JR Jr: Cationic poly(amidoamine) dendrimer induces lysosomal apoptotic pathway at therapeutically relevant concentrations. Biomacromolecules 2009, 10: 3207-3214.

39. Koehler A, Marx U, Broeg K, Bahns S, Bressling J: Effects of nanoparticles in Mytilus edulis gills and hepatopancreas - a new threat to marine life?. Mar Environ Res 2008, 66:12-14.

40. Jin CY, Zhu BS, Wang XF, Lu QH: Cytotoxicity of titanium dioxide nanoparticles in mouse fibroblast cells. Chem Res Toxicol 2008, 21: 1871-1877.

41. Ringwood AH, McCarthy M, Bates TC, Carroll DL: The effects of silver nanoparticles on oyster embryos. Mar Environ Res 2010, 69(Suppl):S49-51.

42. Ringwood AH, Levi-Polyachenko N, Carroll DL: Fullerene exposures with oysters: embryonic, adult, and cellular responses. Environ Sci Technol 2009, 43:7136-7141.

43. Allison AC, Harington JS, Birbeck M: An examination of the cytotoxic effects of silica on macrophages. J Exp Med 1966, 124:141-154.

44. Bendele A, Seely J, Richey C, Sennello G, Shopp G: Short communication: renal tubular vacuolation in animals treated with polyethylene-glycolconjugated proteins. Toxicol Sci 1998, 42:152-157.

45. Hussain S, Thomassen LC, Ferecatu I, Borot MC, Andreau K, Martens JA, Fleury J, Baeza-Squiban A, Marano F, Boland S: Carbon black and titanium dioxide nanoparticles elicit distinct apoptotic pathways in bronchial epithelial cells. Particle and fibre toxicology 2010, 7:10.

46. Chen HH, Yu C, Ueng TH, Chen S, Chen BJ, Huang KJ, Chiang LY: Acute and subacute toxicity study of water-soluble polyalkylsulfonated $\mathrm{C} 60$ in rats. Toxicol Pathol 1998, 26:143-151.

47. Cho WS, Duffin R, Howie SE, Scotton CJ, Wallace WA, Macnee W, Bradley M, Megson IL, Donaldson K: Progressive severe lung injury by zinc oxide nanoparticles; the role of $\mathrm{Zn} 2+$ dissolution inside lysosomes. Particle and fibre toxicology 2011, 8:27.

48. Hamilton RF, Wu N, Porter D, Buford M, Wolfarth M, Holian A: Particle length-dependent titanium dioxide nanomaterials toxicity and bioactivity. Particle and fibre toxicology 2009, 6:35

49. Lunov O, Syrovets T, Loos C, Nienhaus GU, Mailander V, Landfester K, Rouis M, Simmet T: Amino-Functionalized Polystyrene Nanoparticles Activate the NLRP3 Inflammasome in Human Macrophages. ACS Nano 2011, 5:9648-9657.

50. Futerman $\mathrm{AH}$, van Meer $\mathrm{G}$ : The cell biology of lysosomal storage disorders. Nat Rev Mol Cell Biol 2004, 5:554-565.

51. Aldenhoven M, Sakkers RJ, Boelens J, de Koning TJ, Wulffraat NM: Musculoskeletal manifestations of lysosomal storage disorders. Ann Rheum Dis 2009, 68:1659-1665.

52. Bellettato CM, Scarpa M: Pathophysiology of neuropathic lysosomal storage disorders. J Inherit Metab Dis 2010, 33:347-362.

53. Settembre C, Fraldi A, Jahreiss L, Spampanato C, Venturi C, Medina D, de Pablo R, Tacchetti C, Rubinsztein DC, Ballabio A: A block of autophagy in lysosomal storage disorders. Hum Mol Genet 2008, 17:119-129.

54. Schneider P, Korolenko TA, Busch U: A review of drug-induced lysosomal disorders of the liver in man and laboratory animals. Microsc Res Tech 1997, 36:253-275.

55. Kovacs AL, Seglen PO: Inhibition of hepatocytic protein degradation by inducers of autophagosome accumulation. Acta Biol Med Ger 1982, 41:125-130.

56. Shcharbin D, Jokiel M, Klajnert B, Bryszewska M: Effect of dendrimers on pure acetylcholinesterase activity and structure. Bioelectrochemistry 2006, 68:56-59.

57. Ueng TH, Kang JJ, Wang HW, Cheng YW, Chiang LY: Suppression of microsomal cytochrome P450-dependent monooxygenases and mitochondrial oxidative phosphorylation by fullerenol, a polyhydroxylated fullerene C60. Toxicol Lett 1997, 93:29-37.

58. Xia T, Kovochich M, Liong M, Zink Jl, Nel AE: Cationic polystyrene nanosphere toxicity depends on cell-specific endocytic and mitochondrial injury pathways. ACS Nano 2008, 2:85-96.

59. Thibodeau MS, Giardina C, Knecht DA, Helble J, Hubbard AK: Silica-induced apoptosis in mouse alveolar macrophages is initiated by lysosomal enzyme activity. Toxicol Sci 2004, 80:34-48.

60. Franchi L, Eigenbrod T, Munoz-Planillo R, Nunez G: The inflammasome: a caspase-1-activation platform that regulates immune responses and 
disease pathogenesis. Nat Immunol 2009, 10:241-247.

61. Meunier E, Coste A, Olagnier D, Authier H, Lefevre L, Dardenne C, Bernad J, Beraud M, Flahaut E, Pipy B: Double-walled carbon nanotubes trigger IL1 beta release in human monocytes through Nlrp3 inflammasome activation. Nanomedicine 2011, [epub ahead of print].

62. Nakashima S, Hiraku Y, Tada-Oikawa S, Hishita T, Gabazza EC, Tamaki S, Imoto I, Adachi Y, Kawanishi S: Vacuolar H+-ATPase inhibitor induces apoptosis via lysosomal dysfunction in the human gastric cancer cell line MKN-1. J Biochem 2003, 134:359-364.

63. Chen ZH, Lam HC, Jin Y, Kim HP, Cao J, Lee SJ, Ifedigbo E, Parameswaran H, Ryter SW, Choi AM: Autophagy protein microtubule-associated protein 1 light chain-3B (LC3B) activates extrinsic apoptosis during cigarette smoke-induced emphysema. Proc Natl Acad Sci USA 2010, 107:1888018885.

64. Pyo JO, Jang MH, Kwon YK, Lee HJ, Jun Jl, Woo HN, Cho DH, Choi B, Lee H, Kim JH, Mizushima N, Oshumi Y, Jung YK: Essential roles of Atg5 and FADD in autophagic cell death: dissection of autophagic cell death into vacuole formation and cell death. J Biol Chem 2005, 280:20722-20729.

65. Yousefi S, Perozzo R, Schmid I, Ziemiecki A, Schaffner T, Scapozza L, Brunner T, Simon HU: Calpain-mediated cleavage of Atg5 switches autophagy to apoptosis. Nat Cell Biol 2006, 8:1124-1132.

66. Wei Y, Sinha S, Levine B: Dual role of JNK1-mediated phosphorylation of BCl-2 in autophagy and apoptosis regulation. Autophagy 2008, 4:949-951.

67. Wu YC, Wu WK, Li Y, Yu L, Li ZJ, Wong CC, Li HT, Sung JJ, Cho CH: Inhibition of macroautophagy by bafilomycin A1 lowers proliferation and induces apoptosis in colon cancer cells. Biochem Biophys Res Commun 2009, 382:451-456.

68. White E, DiPaola RS: The double-edged sword of autophagy modulation in cancer. Clin Cancer Res 2009, 15:5308-5316.

69. Qu X, Yu J, Bhagat G, Furuya N, Hibshoosh H, Troxel A, Rosen J, Eskelinen EL, Mizushima N, Ohsumi Y, Cattoretti G, Levine B: Promotion of tumorigenesis by heterozygous disruption of the beclin 1 autophagy gene. J Clin Invest 2003, 112:1809-1820.

70. Livesey KM, Tang D, Zeh HJ, Lotze MT: Autophagy inhibition in combination cancer treatment. Curr Opin Investig Drugs 2009, 10: 1269-1279.

71. Brest P, Corcelle EA, Cesaro A, Chargui A, Belaid A, Klionsky DJ, VouretCraviari V, Hebuterne X, Hofman P, Mograbi B: Autophagy and Crohn's disease: at the crossroads of infection, inflammation, immunity, and cancer. Curr Mol Med 2010, 10:486-502.

72. Moreira PI, Santos RX, Zhu X, Lee HG, Smith MA, Casadesus G, Perry G: Autophagy in Alzheimer's disease. Expert Rev Neurother 2010, 10:1209-1218.

73. Pan T, Kondo S, Le W, Jankovic J: The role of autophagy-lysosome pathway in neurodegeneration associated with Parkinson's disease. Brain 2008, 131:1969-1978.

74. Gazouli M, Pachoula I, Panayotou I, Mantzaris G, Chrousos G, Anagnou NP, Roma-Giannikou E: NOD2/CARD15, ATG16L1 and IL23R gene polymorphisms and childhood-onset of Crohn's disease. World J Gastroenterol 2010, 16:1753-1758

75. Geisler S, Holmstrom KM, Treis A, Skujat D, Weber SS, Fiesel FC, Kahle PJ, Springer W: The PINK1/Parkin-mediated mitophagy is compromised by PD-associated mutations. Autophagy 2010, 6:871-878.

76. Lapaquette P. Darfeuille-Michaud A: Abnormalities in the handling of intracellular bacteria in Crohn's disease. J Clin Gastroenterol 2010, 44(Suppl 1):S26-29.

77. Mak SK, McCormack AL, Manning-Bog AB, Cuervo AM, Di Monte DA: Lysosomal degradation of alpha-synuclein in vivo. J Biol Chem 2010, 285:13621-13629.

78. Pickford F, Masliah E, Britschgi M, Lucin K, Narasimhan R, Jaeger PA, Small S, Spencer B, Rockenstein E, Levine B, Wyss-Coray T: The autophagy-related protein beclin 1 shows reduced expression in early Alzheimer disease and regulates amyloid beta accumulation in mice. J Clin Invest 2008, 118:2190-2199.

79. Afeseh Ngwa H, Kanthasamy A, Gu Y, Fang N, Anantharam V, Kanthasamy AG: Manganese nanoparticle activates mitochondrial dependent apoptotic signaling and autophagy in dopaminergic neuronal cells. Toxicol Appl Pharmacol 2011, 256:227-240.

80. Chen Y, Yang L, Feng C, Wen LP: Nano neodymium oxide induces massive vacuolization and autophagic cell death in non-small cell lung cancer NCI-H460 cells. Biochem Biophys Res Commun 2005, 337:52-60.
81. Lee CM, Huang ST, Huang SH, Lin HW, Tsai HP, Wu JY, Lin CM, Chen CT: C (60) fullerene-pentoxifylline dyad nanoparticles enhance autophagy to avoid cytotoxic effects caused by the beta-amyloid peptide. Nanomedicine 2011, 7:107-114.

82. Ma X, Wu Y, Jin S, Tian Y, Zhang X, Zhao Y, Liang XJ Yu L: Gold Nanoparticles Induce Autophagosome Accumulation through SizeDependent Nanoparticle Uptake and Lysosome Impairment. ACS Nano 2011, 5:8629-8639.

83. Khan MI, Mohammad A, Patil G, Naqvi SA, Chauhan LK, Ahmad I: Induction of ROS, mitochondrial damage and autophagy in lung epithelial cancer cells by iron oxide nanoparticles. Biomaterials 2012, 33:1477-1488.

84. Eidi H, Joubert O, Nemos C, Grandemange S, Mograbi B, Foliquet B, Tournebize J, Maincent P, Le Faou A, Aboukhamis I, Rihn BH: Drug delivery by polymeric nanoparticles induces autophagy in macrophages. Int J Pharm 2012, 422:495-503.

85. Zhang $Y$, Yu C, Huang G, Wang C, Wen L: Nano rare-earth oxides induced size-dependent vacuolization: an independent pathway from autophagy. Int J Nanomedicine 2010, 5:601-609.

86. Wei $P$, Zhang $L$, Lu Y, Man N, Wen $L: C 60(N d)$ nanoparticles enhance chemotherapeutic susceptibility of cancer cells by modulation of autophagy. Nanotechnology 2010, 21:495101.

87. Halamoda Kenzaoui B, Chapuis Bernasconi C, Guney-Ayra S, JuilleratJeanneret $L$ : Induction of oxidative stress, lysosome activation and autophagy by nanoparticles in human brain-derived endothelial cells. Biochem J 2012, 441:813-821.

88. Stern ST, Zolnik BS, McLeland CB, Clogston J, Zheng J, McNeil SE: Induction of autophagy in porcine kidney cells by quantum dots: a common cellular response to nanomaterials?. Toxicol Sci 2008, 106:140-152.

89. Li C, Liu H, Sun Y, Wang H, Guo F, Rao S, Deng J, Zhang Y, Miao Y, Guo C, Meng J, Chen X, Li L, Li D, Xu H, Wang H, Li B, Jiang C: PAMAM nanoparticles promote acute lung injury by inducing autophagic cell death through the Akt-TSC2-mTOR signaling pathway. J Mol Cell Biol 2009, 1:37-45

90. Harhaji L, Isakovic A, Raicevic N, Markovic Z, Todorovic-Markovic B, Nikolic N, Vranjes-Djuric S, Markovic I, Trajkovic V: Multiple mechanisms underlying the anticancer action of nanocrystalline fullerene. Eur J Pharmacol 2007, 568:89-98.

91. Wu YN, Yang LX, Shi XY, Li IC, Biazik JM, Ratinac KR, Chen DH, Thordarson P, Shieh DB, Braet F: The selective growth inhibition of oral cancer by iron core-gold shell nanoparticles through mitochondria-mediated autophagy. Biomaterials 2011, 32:4565-4573.

92. Yu JX, Li TH: Distinct biological effects of different nanoparticles commonly used in cosmetics and medicine coatings. Cell Biosci 2011, 1:19.

93. Reale M, Vianale G, Lotti LV, Mariani-Costantini R, Perconti S, Cristaudo A, Leopold K, Antonucci A, Di Giampaolo L, lavicoli I, Di Gioacchino M, Boscolo $P$ : Effects of palladium nanoparticles on the cytokine release from peripheral blood mononuclear cells of palladium-sensitized women. J Occup Environ Med 2011, 53:1054-1060.

94. Liu HL, Zhang YL, Yang N, Zhang YX, Liu XQ, Li CG, Zhao Y, Wang YG, Zhang GG, Yang P, Guo F, Sun Y, Jiang CY: A functionalized single-walled carbon nanotube-induced autophagic cell death in human lung cells through Akt-TSC2-mTOR signaling. Cell Death Dis 2011, 2:e159.

95. Li JJ, Hartono D, Ong CN, Bay BH, Yung LY: Autophagy and oxidative stress associated with gold nanoparticles. Biomaterials 2010, 31: 5996-6003.

96. Zhang $Q$, Yang $W$, Man N, Zheng F, Shen Y, Sun K, Li Y, Wen LP: Autophagy-mediated chemosensitization in cancer cells by fullerene C60 nanocrystal. Autophagy 2009, 5:1107-1117.

97. Yu L, Lu Y, Man N, Yu SH, Wen LP: Rare earth oxide nanocrystals induce autophagy in HeLa cells. Small 2009, 5:2784-2787.

98. Yamawaki H, Iwai N: Cytotoxicity of water-soluble fullerene in vascular endothelial cells. Am J Physiol Cell Physiol 2006, 290:C1495-1502.

99. Yoshikawa Y, Ogawa M, Hain T, Yoshida M, Fukumatsu M, Kim M, Mimuro H, Nakagawa I, Yanagawa T, Ishii T, Kakizuka A, Sztul E, Chakraborty T, Sasakawa C: Listeria monocytogenes ActA-mediated escape from autophagic recognition. Nat Cell Biol 2009, 11:1233-1240.

100. Zheng YT, Shahnazari S, Brech A, Lamark T, Johansen T, Brumell JH: The adaptor protein p62/SQSTM1 targets invading bacteria to the autophagy pathway. J Immunol 2009, 183:5909-5916.

101. Calzolai L, Franchini F, Gilliland D, Rossi F: Protein-nanoparticle interaction: 
identification of the ubiquitin-gold nanoparticle interaction site. Nano Lett 2010, 10:3101-3105.

102. Chen M, von Mikecz A: Formation of nucleoplasmic protein aggregates impairs nuclear function in response to $\mathrm{SiO} 2$ nanoparticles. Exp Cell Res 2005, 305:51-62.

103. Shrivas K, Wu HF: Modified silver nanoparticle as a hydrophobic affinity probe for analysis of peptides and proteins in biological samples by using liquid-liquid microextraction coupled to AP-MALDI-ion trap and MALDI-TOF mass spectrometry. Anal Chem 2008, 80:2583-2589.

104. von Mikecz A, Chen M, Rockel T, Scharf A: The nuclear ubiquitinproteasome system: visualization of proteasomes, protein aggregates, and proteolysis in the cell nucleus. Methods Mol Biol 2008, 463:191-202.

105. Wu HF, Kailasa SK, Shastri L: Electrostatically self-assembled azides on zinc sulfide nanoparticles as multifunctional nanoprobes for peptide and protein analysis in MALDI-TOF MS. Talanta 2010, 82:540-547.

106. Powell AC, Paciotti GF, Libutti SK: Colloidal gold: a novel nanoparticle for targeted cancer therapeutics. Methods Mol Biol 2010, 624:375-384.

107. Anderson N, Borlak J: Drug-induced phospholipidosis. FEBS Lett 2006 580:5533-5540.

108. Roberts JC, Bhalgat MK, Zera RT: Preliminary biological evaluation of polyamidoamine (PAMAM) Starburst dendrimers. J Biomed Mater Res 1996, 30:53-65.

109. Lee J, Giordano S, Zhang J: Autophagy, mitochondria and oxidative stress: cross-talk and redox signalling. Biochem J 2012, 441:523-540.

110. Shi CS, Shenderov K, Huang NN, Kabat J, Abu-Asab M, Fitzgerald KA, Sher A, Kehrl JH: Activation of autophagy by inflammatory signals limits IL-1beta production by targeting ubiquitinated inflammasomes for destruction. Nat Immunol 2012, 13:255-263.

111. Kim I, Lemasters JJ: Mitophagy Selectively Degrades Individual Damaged Mitochondria After Photoirradiation. Antioxid Redox Signal 2011, 14:1919-1928.

112. Elmore SP, Qian T, Grissom SF, Lemasters JJ: The mitochondrial permeability transition initiates autophagy in rat hepatocytes. FASEB $\lrcorner$ 2001, 15:2286-2287.

113. Degtyarev M, De Maziere A, Orr C, Lin J, Lee BB, Tien JY, Prior WW, van Dijk S, Wu H, Gray DC, Davis DP, Stern HM, Murray LJ, Hoeflich KP, Klumperman J, Friedman LS, Lin K: Akt inhibition promotes autophagy and sensitizes PTEN-null tumors to lysosomotropic agents. J Cell Biol 2008, 183:101-116.

114. Boya P, Gonzalez-Polo RA, Casares N, Perfettini JL, Dessen P, Larochette N, Metivier D, Meley D, Souquere S, Yoshimori T, Pierron G, Codogno P, Kroemer G: Inhibition of macroautophagy triggers apoptosis. Mol Cell Biol 2005, 25:1025-1040

115. Yamawaki $\mathrm{H}$, Iwai $\mathrm{N}$ : Mechanisms underlying nano-sized air-pollutionmediated progression of atherosclerosis: carbon black causes cytotoxic injury/inflammation and inhibits cell growth in vascular endothelial cells. Circ J 2006, 70:129-140.

116. Oberdörster G, Ferin J, Soderholm S, Gelein R, Cox C, Baggs R, Morrow PE: Increased Pulmonary Toxicity of Inhaled Ultrafine Particles: Due to Lung Overload Alone?. Ann Occup Hyg 1994, 38:295-302.

117. Levine B: Eating oneself and uninvited guests: autophagy-related pathways in cellular defense. Cell 2005, 120:159-162.

118. Korolchuk VI, Mansilla A, Menzies FM, Rubinsztein DC: Autophagy inhibition compromises degradation of ubiquitin-proteasome pathway substrates. Mol Cell 2009, 33:517-527.

119. Berndt C, Kurz T, Selenius M, Fernandes AP, Edgren MR, Brunk UT: Chelation of lysosomal iron protects against ionizing radiation. Biochem J 2010, 432:295-301.

120. Groth-Pedersen L, Ostenfeld MS, Hoyer-Hansen M, Nylandsted J, Jaattela M: Vincristine induces dramatic lysosomal changes and sensitizes cancer cells to lysosome-destabilizing siramesine. Cancer Res 2007, 67:2217-2225.

121. Huynh C, Roth D, Ward DM, Kaplan J, Andrews NW: Defective lysosomal exocytosis and plasma membrane repair in Chediak-Higashi/beige cells. Proc Natl Acad Sci USA 2004, 101:16795-16800.

122. Montgomery RR, Webster P, Mellman I: Accumulation of indigestible substances reduces fusion competence of macrophage lysosomes. J Immunol 1991, 147:3087-3095.

123. Gall EA Altemeier WA Schiff L, Hamilton DL, Braunstein $H$, Guiseffi J Jr: Freiman DG: Liver lesions following intravenous administration of polyvinyl pyrrolidone. Am J Clin Pathol 1953, 23:1187-1198.

124. Blankson H, Holen I, Seglen PO: Disruption of the cytokeratin cytoskeleton and inhibition of hepatocytic autophagy by okadaic acid. Exp Cell Res 1995, 218:522-530
125. Seglen $\mathrm{PO}$, Brinchmann MF: Purification of autophagosomes from rat hepatocytes. Autophagy 2010, 6:542-547.

126. Kochl R, Hu XW, Chan EY, Tooze SA: Microtubules facilitate autophagosome formation and fusion of autophagosomes with endosomes. Traffic (Copenhagen, Denmark) 2006, 7:129-145

127. Xie R, Nguyen S, McKeehan WL, Liu L: Acetylated microtubules are required for fusion of autophagosomes with lysosomes. BMC Cell Biol 2010, 11:89.

128. Reggiori F, Monastyrska I, Shintani T, Klionsky DJ: The actin cytoskeleton is required for selective types of autophagy, but not nonspecific autophagy, in the yeast Saccharomyces cerevisiae. Mol Biol Cell 2005, 16:5843-5856.

129. Monastyrska I, He C, Geng J, Hoppe AD, Li Z, Klionsky DJ: Arp2 links autophagic machinery with the actin cytoskeleton. Mol Biol Cell 2008, 19:1962-1975

130. Lee JY, Koga H, Kawaguchi Y, Tang W, Wong E, Gao YS, Pandey UB, Kaushik S, Tresse E, Lu J, Taylor JP, Cuervo AM, Yao TP: HDAC6 controls autophagosome maturation essential for ubiquitin-selective qualitycontrol autophagy. EMBO J 2010, 29:969-980.

131. Ehrenberg M, McGrath JL: Binding between particles and proteins in extracts: implications for microrheology and toxicity. Acta Biomater 2005, 1:305-315.

132. Ruenraroengsak $P$, Florence AT: Biphasic interactions between a cationic dendrimer and actin. J Drug Target 2010, 18:803-811.

133. Walker VG, Li Z, Hulderman T, Schwegler-Berry D, Kashon ML, Simeonova PP: Potential in vitro effects of carbon nanotubes on human aortic endothelial cells. Toxicol Appl Pharmacol 2009, 236:319-328.

134. Mironava T, Hadjiargyrou M, Simon M, Jurukovski V, Rafailovich MH: Gold nanoparticles cellular toxicity and recovery: effect of size, concentration and exposure time. Nanotoxicology 2010, 4:120-137.

135. Wu X, Tan Y, Mao H, Zhang M: Toxic effects of iron oxide nanoparticles on human umbilical vein endothelial cells. Int J Nanomedicine 2010, 5:385-399.

136. Mintzer MA, Grinstaff MW: Biomedical applications of dendrimers: a tutorial. Chem Soc Rev 2011, 40:173-190.

137. Nie Y, Zhang ZR, Duan YR: Combined use of polycationic peptide and biodegradable macromolecular polymer as a novel gene delivery system: a preliminary study. Drug Deliv 2006, 13:441-446.

138. Pietersz GA, Tang CK, Apostolopoulos V: Structure and design of polycationic carriers for gene delivery. Mini Rev Med Chem 2006, 6:12851298

139. Seleverstov O, Phang JM, Zabirnyk O: Semiconductor nanocrystals in autophagy research: methodology improvement at nanosized scale. Methods Enzymol 2009, 452:277-296.

140. Choi KM, Nam HY, Na JH, Kim SW, Kim SY, Kim K, Kwon IC, Ahn HJ: A monitoring method for Atg4 activation in living cells using peptideconjugated polymeric nanoparticles. Autophagy 2011, 7:1052-1062.

doi:10.1186/1743-8977-9-20

Cite this article as: Stern et al: Autophagy and lysosomal dysfunction as emerging mechanisms of nanomaterial toxicity. Particle and Fibre Toxicology 2012 9:20

\section{Submit your next manuscript to BioMed Central and take full advantage of:}

- Convenient online submission

- Thorough peer review

- No space constraints or color figure charges

- Immediate publication on acceptance

- Inclusion in PubMed, CAS, Scopus and Google Scholar

- Research which is freely available for redistribution 